\title{
Membrane-Based Operations in the Fruit Juice Processing Industry: A Review
}

\author{
Carmela Conidi ${ }^{1}$, Roberto Castro-Muñoz ${ }^{2}$ (D) and Alfredo Cassano ${ }^{1, *(\mathbb{D})}$ \\ 1 Institute on Membrane Technology, ITM-CNR, c/o University of Calabria, Via P. Bucci 17/C, \\ 87030 Rende (CS), Italy; c.conidi@itm.cnr.it \\ 2 Tecnologico de Monterrey, Campus Toluca. Avenida Eduardo Monroy Cárdenas 2000 San Antonio \\ Buenavista, 50110 Toluca de Lerdo, Mexico; food.biotechnology88@gmail.com \\ * Correspondence: a.cassano@itm.cnr.it; Tel.: +39-0984-492067
}

Received: 20 January 2020; Accepted: 9 March 2020; Published: 16 March 2020

\begin{abstract}
The fruit juice industry is one of the food sectors that has invested the most in the implementation of new technologies, such as non-thermal technologies. Among them, membrane processes are considered today well-established separation techniques to support the production and marketing of innovative fruit juices designed to exploit the sensory characteristics and nutritional peculiarities of fresh fruits. Pressure-driven membrane operations, membrane distillation, osmotic distillation and pervaporation have been widely investigated in the last few decades to replace conventional technologies used in fruit juice processing industry (i.e., clarification, stabilization, concentration and recovery of aroma compounds). This paper will review the significant progresses on the use of membrane-based operations in fruit juice processing industry in the light of the growing interest towards products with improved safety, quality and nutritional value and sustainable processes characterized by low energy consumption and low environmental impact.
\end{abstract}

Keywords: fruit juices; clarification; concentration; pressure-driven membrane operations; aroma recovery; membrane distillation; osmotic distillation; pervaporation; integrated membrane processes

\section{Introduction}

The consumption of fruit juices has significantly increased during last years and it is growing remarkably, since consumers are interested in healthy products which are practical and ready to be consumed. Thus, the global fruit and vegetable processing market was valued at USD 230.96 billion in 2016 and is projected to grow at a CAGR of 7.1\% from 2017, to reach USD 346.05 billion by 2022 [1].

Fruit juices act as nutritional beverages and can play a significant part in a healthy diet because they offer a chemical composition that are naturally found in fruits. In addition, to being rich in nutrients with a wide range of vitamins, minerals, protein, and varied source of protective antioxidants, fruit juices also have the ability to impart equivalent energy. This, coupled with the refreshing taste and longer shelf-life of fruit juices, make them one of the most requested beverages.

In the design of fruit juice processing, safety and quality improvement, nutritional value, consumer convenience and acceptance, product and process cost minimization have always been fundamental aspects [2].

Conventional methods for the production of single strength or concentrated juices involve several batch operations that are labour- and time-consuming. A typical flow sheet involves: (1) a mechanical pressing of the juice from the fruit pulp; (2) the juice extraction; (3) the clarification of the juice by centrifugation or filtration; (4) a concentration step by multistep vacuum evaporation (Figure 1). 


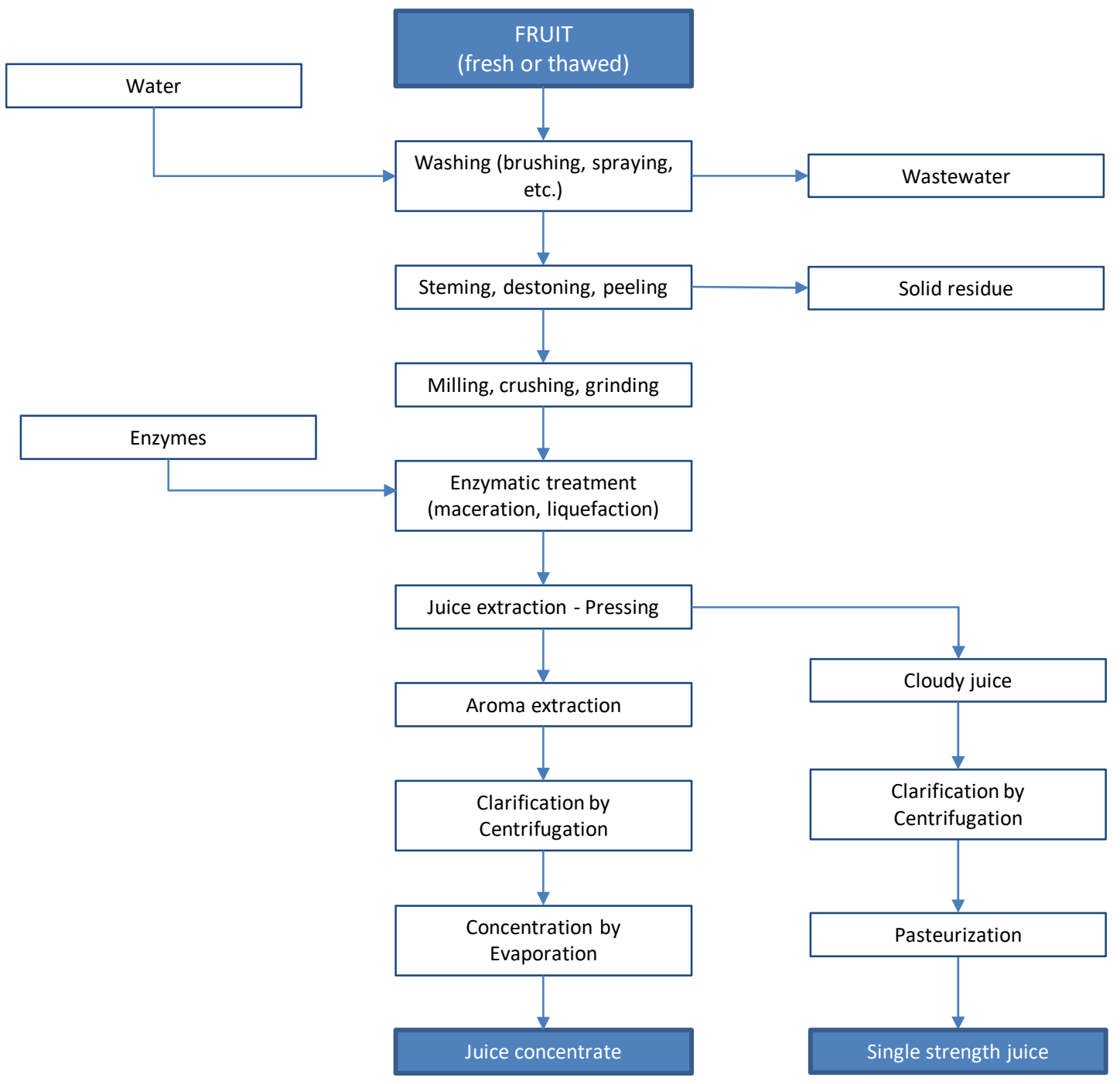

Figure 1. Scheme of conventional fruit juice processing.

Membrane technology is a valid approach for juice concentration and clarification offering several advantages over traditional separation processes including high selectivity based on unique separation mechanisms, no thermal stress of processed fluids due to moderate operating temperatures, no use of chemical additives, easy scale-up, compact and modular design, low energy consumption [3]. In particular, pressure-driven membrane operations, including microfiltration (MF), ultrafiltration (UF), nanofiltration (NF) and reverse osmosis (RO) represent the state-of-the-art technology for juice clarification, fractionation and concentration [4]. In the last years, other membrane operations such as osmotic distillation (OD), membrane distillation (MD) and pervaporation (PV) have been used for juice concentration and recovery of aroma compounds.

The application of membrane technologies for the production of fruit juices fits well with the new strategies of sustainable food processing (SFP), based on the use of low energy and low impact environmental processing schemes. Moreover, thanks to mild operating conditions, the membrane treatment does not deteriorate the product quality as much as traditional thermal processing [5].

The global market of membrane technology for food and beverage processing is estimated to reach about $\$ 8.26$ billion by 2024, growing at a CAGR of $6.8 \%$ over the forecast period (2019-2024) [6].

The aim of this paper is to provide an overview of the recent developments of membrane operations in the clarification, concentration and recovery of aroma compounds in fruit juice processing. Section 1 of the paper will provide an overview of the general principles of membrane processes; specific 
applications and related technological advances and improvements over conventional methodologies will be analyzed and discussed in Section 2.

\section{Fundamentals of Membrane Operations}

\subsection{Pressure-Driven Membrane Operations}

Pressure-driven membrane operations are commonly classified into four categories in order of increasing selectivity: microfiltration (MF), ultrafiltration (UF), nanofiltration (NF) and reverse osmosis (RO). In these processes a semi-permeable barrier, named membrane, is used to enable the selective separation of the compounds in the feed solution under a pressure gradient acting as driving force for the mass transport through the membrane. As a result, the feed solution is separated into a filtrate or permeate containing all particles or molecules which have permeated the membrane and a retentate containing all compounds rejected by the membrane [7]. The degree of rejection depends on the properties of the membrane such as the pore size, the charge and the surface properties. In particular, the charge of the membrane is significant to membrane performance because charge affects the electrostatic repulsion between the ions or charged molecules and the membrane surface [8]. Membranes can acquire an electric charge when brought in contact with aqueous electrolyte solutions through dissociation of functional groups, adsorption of ions, polyelectrolytes, ionic surfactants and charged macromolecules. These surface charges have an influence on the distribution of ions in the solution due to the requirement of the electroneutrality of the system.

MF membranes contain macropores with pore size range of $0.05-2 \mu \mathrm{m}$; they are primarily used to separate particles and bacteria from other smaller solutes. Typical operating pressures are of the order of 0.5-2 bar [9]. The UF process is based on the use of asymmetric membranes with pore sizes in the skin layer of 2-10 nm. Typically, dissolved molecules or small particles not larger than $0.1 \mu \mathrm{m}$ in diameter are retained. UF membranes are characterized by the molecular weight cut-off (MWCO), defined as the equivalent molecular weight of the smallest species that exhibit $90 \%$ rejection [10]. Typically, macromolecules in the range 103-106 Dalton are rejected. Operating pressures are of the order of 1-10 bar.

NF membranes have separation capabilities intermediate between those of UF and RO membranes. Membrane pore sizes are in the range $0.5-2 \mathrm{~nm}$ while operating pressures range between 5 and 40 bar. NF is essentially used to achieve a separation between sugars, other organic molecules, and multivalent salts on one hand and monovalent salts and water on the other. Indeed, most NF membranes are electrically charged in aqueous media and their separation mechanisms involve not only steric effects but also charge effects [11].

$\mathrm{RO}$ membranes are generally used to separate low molecular weight compounds from a relatively pure solvent. The particle size range for $\mathrm{RO}$ applications is between 0.1 and $1 \mathrm{~nm}$ and solutes with molecular weight greater than 300 Da are separated. The hydrostatic pressures to obtain significant transmembrane flux can vary from 10 to 100 bar depending upon the osmotic pressure of the feed mixture. The separation mechanism is affected by size and shape of molecules as well as ionic charge and specific interactions between the species and the membrane [12].

The performance of pressure-driven membrane processes is mainly assessed through the measurement of productivity (permeate flux) and degree of separation. The volumetric flux $J_{p}\left(\mathrm{~L} / \mathrm{m}^{2} \mathrm{~h}\right)$, which is the throughput per unit area of membrane, is defined as:

$$
J_{p}=\frac{V_{p}}{A \cdot t}
$$

where $V_{p}$ is the volume of permeate (L) collected in a certain time $t(\mathrm{~h})$ through the membrane surface area $A\left(\mathrm{~m}^{2}\right)$. 
The membrane rejection $(R)$ coefficient reflects the membrane selectivity and can be calculated for each solute as:

$$
R=\left(1-\frac{C_{p}}{C_{f}}\right) \cdot 100
$$

where $C_{p}$ is the solute concentration in the permeate and $C_{f}$ the solute concentration in the feed. Rejection values are between $0 \%$ (for solutes having highest probability to pass through the membrane) and $100 \%$ (when solutes are completely retained by the membrane).

Polymeric membranes dominate the industrial market of pressure-driven membrane operations. They are relatively cheap, easy to manufacture and available in a wide range of pore sizes. The most common polymeric membranes are manufactured from cellulose acetate (CA), polysulphone (PS), polyethersulphone (PES), polytetrafluoroethylene (PTFE), polypropylene (PP), polyethylene (PE), polyvinylidene fluoride (PVDF), polyacrylonitrile (PAN) and polyamide (PA). Ceramic membranes are manufactured from inorganic materials (e.g., alumina, zirconia, titania, and silica). They exhibit a strong tolerance to aggressive media (acids, alkalis, strong solvents) as well as high mechanical and thermal stability. Although their production costs are higher than those of polymeric membranes they are ecologically friendly, durable and have a longer lifetime [7,13].

For continuous membrane operations, membranes are installed in proper devices known as membrane modules. On large industrial scale, membrane modules are available in five basic designs: hollow fiber, spiral wound, tubular, plate and frame and capillary. They are quite different in their design, mode of operation, production costs and energy requirement for pumping the feed solution through the module. The membrane area available in these basic devices is in the range 1-800 $\mathrm{m}^{2}$.

Table 1 summarizes typical species retained by pressure-driven membrane operations in fruit juice processing.

Table 1. Properties of pressure-driven membrane operations.

\begin{tabular}{cccc}
\hline Process & Pore Size & Operating Pressure (bar) & Species Retained \\
\hline MF & $>0.1 \mu \mathrm{m}$ & $0.1-3.0$ & $\begin{array}{c}\text { Bacteria, suspended solids, cells, cell walls, } \\
\text { fibers, crystals, starch, granules }\end{array}$ \\
\hline $\mathrm{UF}$ & $\begin{array}{c}0.1 \mu \mathrm{m}-2 \\
\mathrm{~nm}\end{array}$ & $1-10$ & Polysaccharides, proteins, tannins \\
\hline $\mathrm{NF}$ & $<2 \mathrm{~nm}$ & $10-50$ & $\begin{array}{c}\text { Sugars, organic acids, polyphenols, } \\
\text { aroma compounds, etc. }\end{array}$ \\
\hline $\mathrm{RO}$ & dense & $10-100$ & Salts \\
\hline
\end{tabular}

\subsection{Membrane Distillation and Osmotic Distillation}

Membrane distillation (MD) and osmotic distillation (OD) have attracted considerable interest in the concentration of thermo-sensitive solutions, such as fruit juices, since they operate under atmospheric pressure and room temperature, thus avoiding thermal and mechanical damage of the solutes $[14,15]$.

These processes are based on a water vapor transfer promoted by a vapor pressure difference generated between the two sides of a macroporous hydrophobic membrane. The water transport through the membrane can be summarized in three steps: (1) evaporation of the water from the feed side; (2) water transport, as a vapor, through the membrane's pores; (3) condensation of permeated water on the permeate side [16].

In the OD process the membrane separates two liquid phases at different solute concentration: a dilute solution on one side and a hypertonic salt solution on the opposite side. As stripping solutions, organic solvents (e.g., polyglycerol and glycerol) or inorganic salts (e.g., $\mathrm{CaCl}_{2}, \mathrm{NaCl} \mathrm{MgCl}_{2}$, and $\mathrm{MgSO}_{4}$ ) can be applied [17]. 
The hydrophobic nature of the membrane prevents penetration of the pores by aqueous solutions, creating air gaps within the membrane. The difference in solute concentration, and consequently in water activity of both solutions, generates, at the vapor-liquid interface, a vapor pressure gradient across the membrane causing a water vapor transfer across the pores from the high-vapor pressure phase to the low one (Figure 2).

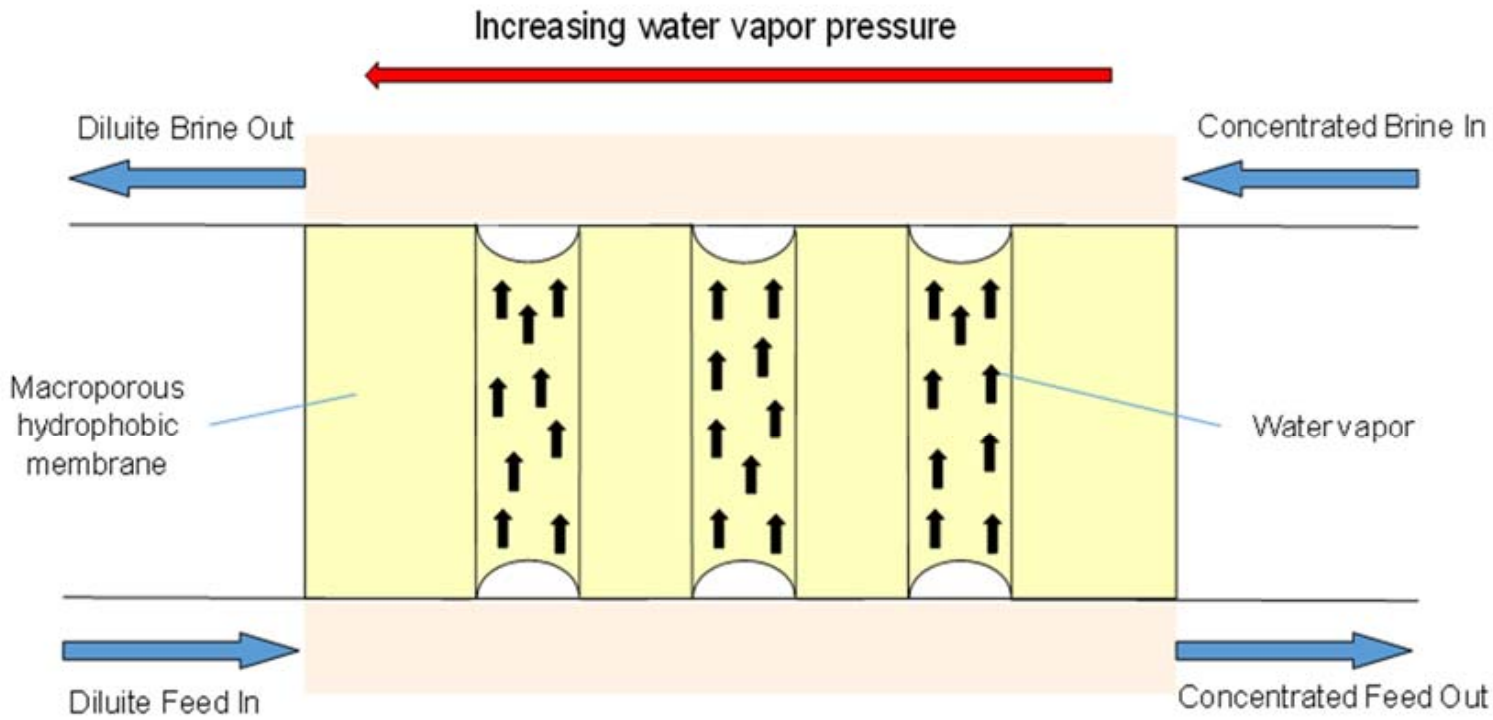

\section{Decreasing water vapor pressure}

Figure 2. Osmotic distillation (OD) process. Scheme of water vapors transport through the membrane from the feed solution to the stripping solution.

The water vapor pressures at the pore mouths are related to the temperature and activities prevailing in the liquids facing the membrane by:

$$
\begin{aligned}
& P_{w 1}=P_{w 1}^{*} \cdot a_{w 1} \\
& P_{w 2}=P_{w 2}^{*} \cdot a_{w 2}
\end{aligned}
$$

in which $P^{*}{ }_{w}$ represents the vapor pressure of pure water and aw the water activity in the solutions. The driving force $\left(\Delta P_{w}=P_{w 1}-P_{w 2}\right)$ for water transport is sustained by the activity difference $\Delta a_{w}=$ $a_{w 1}-a_{w 2}$.

The water transport that relates the mass flux $(J)$ to the driving force is given by:

$$
J=K \cdot \frac{\Delta P_{w}}{p_{a i r}}
$$

where $p_{\text {air }}$ is the mean pressure of air entrapped into pores and $K$ the overall mass transfer coefficient which accounts for all three resistances for water transport (feed, membrane and brine side) [18].

In MD the physical origin of the vapor pressure difference is a temperature gradient rather than a concentration gradient: the feed is maintained at high temperature while cold water is used as a stripping permeate. In these conditions a net pure water vapor flux from the warm side to the cold one occurs [19].

The most common configuration of MD used for the concentration of liquid foods is the direct contact membrane distillation (DCMD) in which both feed and the permeate liquid are in direct contact with the membrane in their respective compartments. Volatile molecules evaporate at the 
hot liquid/vapor interface, cross the membrane pores in the vapor phase and condense on the cold liquid/vapor interface inside the membrane module [20]. In the vacuum membrane distillation (VMD) vacuum is applied on the permeate side of the membrane by means of a vacuum pump and condensation takes place outside the membrane module [21].

Typical hydrophobic membranes for MD and OD applications are manufactured in PP, PE, PVDF and PTFE with high porosity $(70-80 \%)$ and a thickness of 10-300 $\mu \mathrm{m}$.

\subsection{Pervaporation}

Thanks to its ability in separating azeotropic mixtures, pervaporation (PV) has emerged as a potential candidate for replacing conventional distillation. This selective membrane technology separates specific target molecules from azeotropic multicomponent mixtures. Typically, the technique involves separating the liquid mixture by its partial vaporization through a non-porous permselective membrane. The high separation efficiency of PV is attributed to the specific features of the membrane used and the type of mass transport across the membrane. A typical PV membrane should usually possess a dense non-porous structure [22], in which the mass transport is well denoted by the so-called solution-diffusion (S-D) mechanism, as represented in Figure 3. This mechanism depends on specific properties, such as solubility and diffusivity, of the target compounds. In agreement with the S-D theory, the mass transfer can be described by a three-step mechanism involving: (1) a preferential sorption of the molecules from the feed mixture to the "selective" layer of the membrane according to the thermodynamic equilibrium at the liquid-membrane interface; (2) the diffusion of the adsorbed molecules through the membrane as a result of the concentration gradient; (3) the desorption of the molecules on the membrane/permeate interface [23].

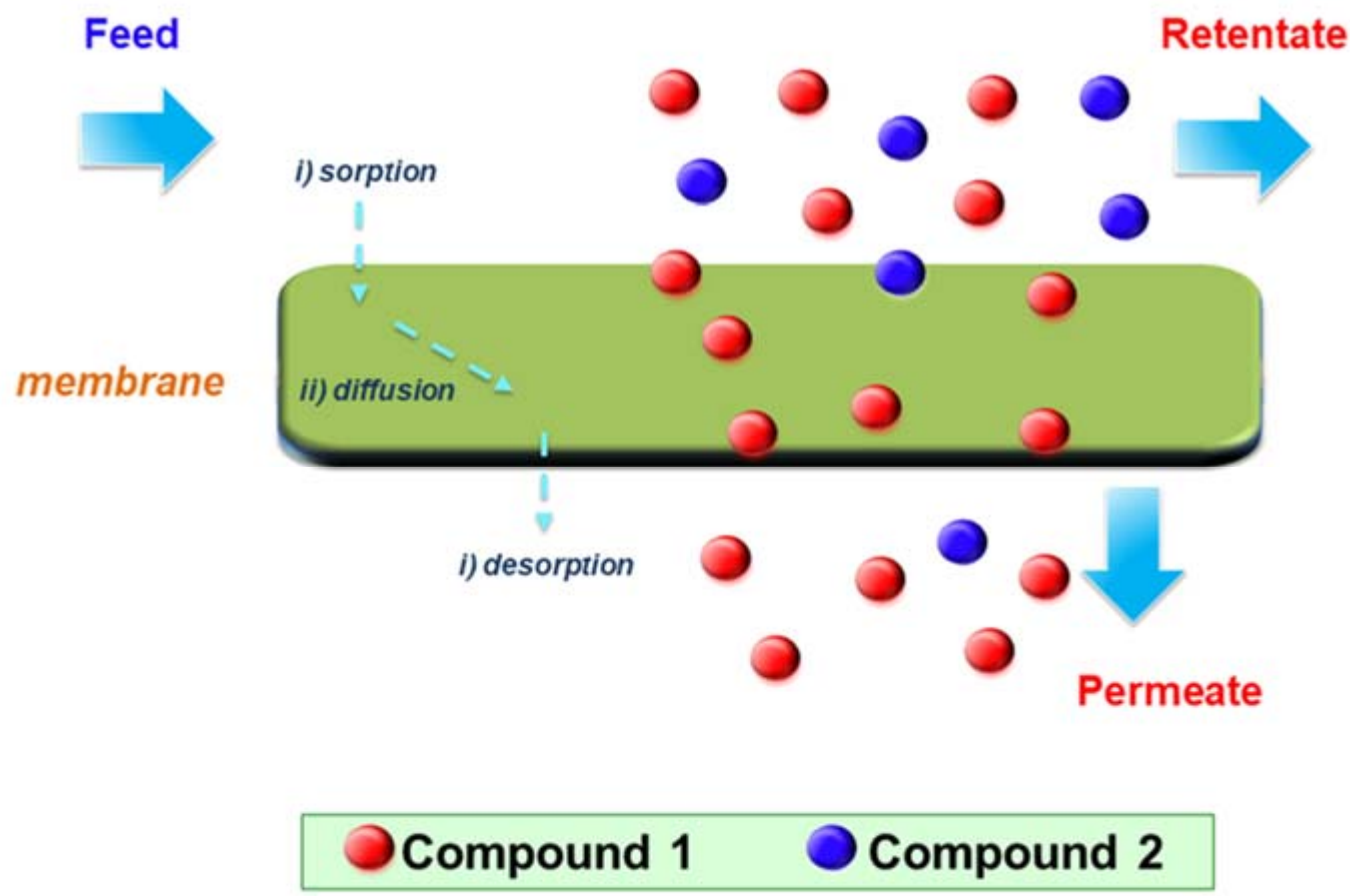

Figure 3. Mass transfer in pervaporation: description of solution-diffusion mechanism.

To carry out the separation, the feed mixture (in liquid state) needs to be in direct contact with the "selective" layer of the membrane. By applying vacuum pressure as a driving force, a phase change of the feed mixture from liquid to gas state occurs, and the compounds (in gas or vapor state) are then transported across the membrane to the permeate side. The permeate will mainly contain the permeating species which display a higher affinity to the membrane. PV membranes can be hydrophilic or hydrophobic. For instance, hydrophilic membranes preferentially display higher affinity and thus 
preferential transport of polar molecules, including water. It is well known that water is a polar molecule since possess bonds between hydrogen and oxygen; moreover, alcohols are also polar molecules due to the plenty -OH groups, providing a slight negative charge. Generally, the polarity of different organics has been denoted as: amide $>$ acid $>$ alcohol $>$ ketone aldehyde $>$ amine $>$ ester $>$ ether $>$ alkane [24]. On the other hand, when dealing with the use of hydrophobic membranes, they favor the preferential transport of non-polar molecules (or less polar compounds).

The performance of the PV process is generally evaluated using basic parameters, including permeate flux $(J)$ and separation factor $(\alpha)$. The term $J$ represents the productivity of the process, whereas the $\alpha$ one gives an input of the selective features of the membrane. The calculation of $J$ is generally performed as follows:

$$
J=\frac{m}{A \cdot t}
$$

where $m$ is the mass amount of specific or total permeating molecules transported through a specific membrane area $A$ to the permeate stream and collected during certain time $t$ [25]. The permeate flux $\left(J_{i}\right)$ of specific molecules (i) can be described by the following equation:

$$
J_{i}=y_{i} \cdot
$$

where $y_{i}$ is the molar fraction of the molecules.

Regarding the separation factor $(\alpha)$ it is calculated as the ratio between the concentration of the molecules A and B in the permeate and retentate side, respectively. Its calculation is based on the following Equation (8):

$$
\propto_{A B}=\frac{\left(C_{A} / C_{B}\right)_{\text {permeate }}}{\left(C_{A} / C_{B}\right)_{\text {feed }}}
$$

where $C$ represent the concentration of the specific component in the feed or permeate.

The corresponding enrichment factor $(\beta)$ of a specific compound is defined as:

$$
\beta_{A}=\frac{\left(C_{A}\right)_{\text {permeate }}}{\left(C_{A}\right)_{\text {feed }}}
$$

It is essential to mention that these basic parameters (i.e., J, $\alpha, \beta$ ) are strongly depending on the process and its operating conditions (e.g., feed concentration, pressure, temperature, among others) [26].

\section{Fruit Juice Clarification}

Natural fruit juices are often opalescent. The indigenous turbidity is caused by the presence of polysaccharides (cellulose, hemicellulose, lignin, pectin and starch), protein in colloidal suspension, tannins and metals $[27,28]$. However, transparency and homogeneity are essential characteristics for consumers.

Traditional methods of fruit juice clarification involve many steps, such as enzymatic treatment (depectinization), cooling, flocculation (gelatin, silica sol, bentonite and diatomaceous), decantation and filtration which labor and time consuming. In addition, these methods are based on the use of large amounts of coadiuvants and additives with further drawbacks, such as the risk of dust inhalation with consequent health problems caused by handling and disposal, environmental problems and significant costs [29].

Pressure driven membrane processes such as MF and UF have been shown to be of great interest for clarification of fruit juices and have become a commercial success. These processes represent a valid alternative to traditional methods of fruit juice clarification and stabilization, resulting in saving in labor and energy input, increased juice yield and avoidance of fining agents (gelatin, bentonite and 
silica sol) and filter aids [4]. The quantity of enzyme for hydrolysis of macromolecules can be reduced and enzymes recycled and reused.

MF and UF are very efficient in the preserving the juice freshness, aroma and nutritional value while obtaining high-quality, natural fresh-tasting and additive-free products as the separation process requires no heat application or the use of chemical agents [30]. In these processes the juice is separated into a fibrous concentrated pulp (retentate) and a clarified fraction free of spoilage microorganisms and totally stable (permeate). These membranes retain high molecular weight compounds (pectin or proteins) and allow low molecular weight solutes (sucrose, acids, salts, aroma and flavor compounds) to permeate through the membrane.

The selection of UF and MF membranes during fruit juice clarification should consider the viscosity of the raw juice, the retention of specific compounds, the sterilization ability and the investment costs of the membranes. For pulpy juices, with high solids content and viscosity, vibrating membrane systems, plate and frame modules with large spacers or large-bore tubular modules, are preferred. However, the tubular configuration is associated with low packing density and high membrane replacement costs. Conversely, hollow fiber membranes present the advantage of high membrane area per volume unit of module, low manufacturing costs and a simple handling in comparison with other membrane configurations. This translates into space-savings, more productivity and reduction of costs also connected to their maintenance, since these modules can be back-flushed [31]. The limit of using this configuration is a clogging of particles in the narrow flow path of the hollow fiber module reducing the permeate flow and interfering with subsequent chemical and mechanical cleaning. At this purpose, the use of thin channel devices requires additional pre-treatments of the raw juice to reduce the overall content of solids.

Different polymeric materials have been employed to produce membranes used in fruit juice clarification. PS membranes have been extensively used for juice UF; they offer a greater resistance to hypochlorites during periodic cleaning cycles in comparison with CA membranes. PVDF, PA and PP have been also widely used for the clarification of different type of juices because they are inexpensive if compared with ceramic membranes. However, the main drawback of polymeric membranes is their low stability in drastic conditions of $\mathrm{pH}$ and consequently, limited shelf-life for juice processing applications. On the other hand, ceramic membranes have greater resistance to chemical degradation, low tendency of fouling, good cleanability and much longer shelf life making them suitable for many applications for which polymeric membranes cannot be used; their disadvantage is the high cost if compared with polymeric membranes [32].

Permeate fluxes and quality of clarified fruit juices are strongly affected by operating conditions, such as cross-flow velocity (CFV), transmembrane pressure (TMP), temperature, volume reduction factor (VRF) and membrane properties such as molecular weight cut-off (MWCO) or pore size and membrane material. In particular, high permeate flux is necessary for filtration to be practical and economic, and product quality should at least meet those obtained by the other standard clarification methods.

The optimization of operating conditions in the production of fruit juices has been investigated by different authors. For instance, Cassano et al. [33] studied, at laboratory scale, the effect of TMP, temperature and feed flowrate on permeate flux and quality during the ultrafiltration of kiwifruit juice with a tubular PVDF membrane module (Series-Cor TM 166 HFM 25, Koch Membrane Systems, Inc., Wilmington, MA, USA) with a MWCO of $15 \mathrm{kDa}$. The highest permeate flux values were obtained at a temperature of $25^{\circ} \mathrm{C}$, a TMP of $90 \mathrm{kDa}$ and a feed flowrate of $700 \mathrm{~L} / \mathrm{h}$. In these conditions the UF process permitted a good level of clarification reducing completely the suspended solids and producing high quality clarified juice with only a $16 \%$ reduction of ascorbic acid with respect to the fresh juice; the reduction of total antioxidant activity was lower than $8 \%$. The recovery of biologically active compounds in the juice clarified with a $30 \mathrm{kDa}$ cellulose acetate membrane resulted dependent of the final VRF of the process: an increase of the VRF produced an increase of glutamic, folic, ascorbic and citric acid in the permeate fraction [34]. 
Laorko et al. [35] studied the effect of operating conditions, pore size and MWCO during the clarification of pineapple juice using MF (pore size of 0.1 and $0.2 \mu \mathrm{m}$ ) and UF (MWCO of 30 and $100 \mathrm{kDa}$ ) membranes. The obtained results showed that the $0.2 \mu \mathrm{m}$ MF membrane, working at a TMP of $0.7 \mathrm{bar}$ and a CFV of $3.4 \mathrm{~m} / \mathrm{s}$, exhibited the highest permeate fluxes and highest recovery of phytochemical compounds and antioxidant activity, if compared with other tested membranes.

Sagu et al. [36] investigated the effect of cross flowrate and TMP on permeate flux, quality and taste of banana juice ultrafiltered with three different hollow fiber polymeric membranes with MWCO of 10, 27 , and $44 \mathrm{kDa}$. The results indicated that the $27 \mathrm{kDa}$ membrane was suitable for the treatment of banana juice due to its highest permeate fluxes and lowest rejection towards physico-chemical compounds. For this membrane, the increase of cross flow velocity from 10 to $20 \mathrm{~L} / \mathrm{h}$, did not affect the permeate fluxes; on the other hand, a decline of permeate flux by increasing the operating pressure, was observed. The variation of operating conditions, during the clarification process, did not affect the juice quality: with the exclusion of alcohol insoluble solids, completely retained by the membrane, other nutritional compounds (including proteins and polyphenols) were recovered in the UF permeate fraction. Results of storage studies indicated that the clarified juice can be stored for 1 month under refrigerated conditions, maintaining the nutritional qualities and taste without adding any preservative substance.

Hollow fiber membranes in PVDF and PS, produced in laboratory, have been also tested for the clarification of pomegranate juice, in order to study the effect of membrane material on the functional properties of the clarified juice [37]. Experimental results indicated that PVDF membranes presented a lower retention towards healthy compounds, including flavonoids and anthocyanins, in comparison to PS membranes. Consequently, the PVDF clarified juice exhibited greater antioxidant effects than the juice clarified with PS membranes. In addition, the treatment with PVDF membranes enriched the juice in $\alpha$-amylase and $\alpha$-glucosidase inhibitors. These results showed that the clarification of pomegranate juice with hollow fiber membranes in PVDF could be a fast and efficient method to produce a clarified juice enriched in health compounds suitable for the production of functional foods and beverages.

The influence of membrane material and MWCO on the quality, content of antioxidant compounds and permeate flux in the clarification of depectinized Valencia orange juice have been studied by Qaid et al. [30]. At this purpose, two flat sheet membranes with different MWCO (20 and $30 \mathrm{kDa})$ and membrane material (PS and PES) were used. Both selected membranes retained suspended solids and pectins preserving, at the same time, the chemical composition of natural fresh juice. However, in the optimized operating conditions of TMP ( 2 bar), feed flowrate $(228 \mathrm{~L} / \mathrm{h})$ and temperature $\left(27^{\circ} \mathrm{C}\right), \mathrm{PES}$ membranes showed higher permeate fluxes in comparison with PS membranes and lower rejection (in the range 6.2-11.32\%) towards antioxidant compounds.

Typical applications of MF and UF membranes in fruit juice clarification are summarized in Table 2. 
Table 2. Fruit juice clarification by MF and UF processes.

\begin{tabular}{|c|c|c|c|c|}
\hline Fruit Juice & Process & Membrane Type & Operating Conditions & Ref. \\
\hline Apple & UF & Tubular, $\mathrm{ZrO}_{2}, 15,50 \mathrm{kDa}, 0.0225 \mathrm{~m}^{2}$ (Carbosep, Rhodia Orelis, Miribel, France) & TMP, $1.5-4$ bar; CFV, $2-7 \mathrm{~m} / \mathrm{s} ; \mathrm{T}, 50-55{ }^{\circ} \mathrm{C}$ & [38] \\
\hline Apple & UF & Flat-sheet, cellulose regenerate, $100 \mathrm{kDa}, 32 \times 102 \mathrm{~m}^{2}$ (Merck Millipore Pvt. Ltd., Bangalore, India) & TMP, 2.7-6.0 bar; stirrer speed, $600-1200 \mathrm{rpm} ; \mathrm{T}, 20-50^{\circ} \mathrm{C}$ & [39] \\
\hline Banana & UF & Hollow fiber, $\mathrm{PS}, 10,27$, and $44 \mathrm{kDa}, 0.026 \mathrm{~m}^{2}$ & TMP, $3.5,5.2,6.9,10.4$ bar; $\mathrm{Q}_{\mathrm{f}}, 10,15,20 \mathrm{~L} / \mathrm{h}, \mathrm{T}, 25^{\circ} \mathrm{C}$ & [36] \\
\hline Black currant & MF & Tubular, ceramic, $0.45 \mu \mathrm{m}, 0.125 \mathrm{~m}^{2}$ & TMP, 3.9 bar; $\mathrm{Q}_{\mathrm{f}}, 500 \mathrm{~L} / \mathrm{h} ; \mathrm{T}, 25^{\circ} \mathrm{C}$ & [40] \\
\hline Bergamot & UF & Hollow fiber, PS, 100 kDa, 0.16 m², (DCQ II-006C-PS100, Blue Star Membrane Technology, Beijing, China) & TMP, 0.7 bar; $\mathrm{Q}_{\mathrm{f}}, 114 \mathrm{~L} / \mathrm{h} ; \mathrm{T}, 24^{\circ} \mathrm{C}$ & [41] \\
\hline \multirow{3}{*}{ Blood orange } & \multirow{3}{*}{ UF } & Hollow fiber, PS, 50 kDa, 0.16 m²$^{2}$ (DCQ II-006C-PS50, Blue Star Membrane Technology) & TMP, 0.5 bar; $\mathrm{Q}_{\mathrm{f}}, 140 \mathrm{~L} / \mathrm{h} ; \mathrm{T}, 20^{\circ} \mathrm{C}$ & \multirow{3}{*}{ [42] } \\
\hline & & Hollow fiber, PS, 100 kDa, 0.16 m², (DCQ II-006C-PS100, Blue Star Membrane Technology, Beijing, China) & TMP, 0.5 bar; $\mathrm{Q}_{\mathrm{f}}, 140 \mathrm{~L} / \mathrm{h} ; \mathrm{T}, 20^{\circ} \mathrm{C}$ & \\
\hline & & Hollow fiber, PAN, 50 KDa, 0.16 m², (DCQ II-006C-PAN50, Blue Star Membrane Technology, Beijing, China) & TMP, 0.5 bar; $\mathrm{Q}_{\mathrm{f}}, 140 \mathrm{~L} / \mathrm{h} ; \mathrm{T}, 20^{\circ} \mathrm{C}$ & \\
\hline Blood orange & UF & Flat-sheet, PES 30, 50 and 100 kDa (Sartorius Stedim Biotech, Göttingen, Germany) & TMP, 1.5 bar; $\mathrm{T}, 24^{\circ} \mathrm{C}$ & [43] \\
\hline \multirow{2}{*}{ Cactus pear } & MF & Flat sheet, PVDF, $0.2 \mu \mathrm{m}, 11.33 \mathrm{~cm}^{2}$ (MV020, Microdyn-Nadir, Wiesbaden, Germany) & TMP, 2.2 bar; $Q_{f}, 500 \mathrm{~L} / \mathrm{h} ; \mathrm{T}, 25^{\circ} \mathrm{C}$ & \multirow{2}{*}[44]{} \\
\hline & UF & Flat sheet, PVDF, $200 \mathrm{kDa}, 11.33 \mathrm{~cm}^{2}$ (Microdyn-Nadir, Wiesbaden, Germany) & TMP, 2.2 bar; $\mathrm{Q}_{\mathrm{f}}, 500 \mathrm{~L} / \mathrm{h} ; \mathrm{T}, 25^{\circ} \mathrm{C}$ & \\
\hline Carrot & MF & Multitubular, $\mathrm{ZrO}_{2} / \mathrm{TiO}_{2}, 0.2 \mu \mathrm{m}, 0.056 \mathrm{~m}^{2}$ (Kerasep, Orelis, Miribel, France) & TMP, 1.8 bar, $\mathrm{Q}_{\mathrm{f}}, 171 \mathrm{~L} / \mathrm{h} ; \mathrm{T}, 25^{\circ} \mathrm{C}$ & [45] \\
\hline Kiwifruit & UF & Tubular, PVDF, 15 kDa, 0.23 m² (HFM 251, Koch Series-CorTM, Koch-Glitsch Italia S.r.l, Milan, Italy) & TMP, 0.9 bar; $\mathrm{Q}_{\mathrm{f}}, 700 \mathrm{~L} / \mathrm{h} ; \mathrm{T}, 25^{\circ} \mathrm{C}$ & [33] \\
\hline Kiwifruit & MF & Fly-ash-based ceramic membranes & TMP, 1.5 bar & [46] \\
\hline Kiwifruit & UF & Flat-sheet, cellulose, $30 \mathrm{kDa}, 38.4 \mathrm{~cm}^{2}$ (C030 FM, Microdyn-Nadir, Wiesbaden, Germany) & TMP, 0.65 bar; $\mathrm{Q}_{\mathrm{f}}, 933 \mathrm{~mL} / \mathrm{min} ; \mathrm{T}, 30^{\circ} \mathrm{C}$ & [34] \\
\hline Orange & MF & $\begin{array}{l}\text { Flat-sheet, alumina, } 0.2 \mu \mathrm{m}, 17 \mathrm{~cm}^{2} \text { (Anopore Membrane Disc, Whatman, Germany); flat-sheet, glass fiber, } 1.2 \mu \mathrm{m}, 17 \mathrm{~cm}^{2} \\
\text { (Discs from Legallais, France) }\end{array}$ & TMP, 1.5 bar; $\mathrm{T}, 25^{\circ} \mathrm{C}$ & [47] \\
\hline Blood orange & UF & Tubular, PVDF, 15 kDa, 0.23 m² (HFM 251, Koch Series-CorTM, Koch-Glitsch Italia S.r.l., Milan, Italy) & TMP, 0.85 bar; $\mathrm{Q}_{\mathrm{f}}, 800 \mathrm{~L} / \mathrm{h} ; \mathrm{T}, 25^{\circ} \mathrm{C}$ & [48] \\
\hline \multirow{2}{*}{ Red plum } & MF & Flat-sheet, PVDF, $0.22 \mu \mathrm{m}, 0.0209 \mathrm{~m}^{2}$ (Millipore, Billerica, MA, USA) & TMP, $0.5-2.9$ bar; $\mathrm{T}, 20-40^{\circ} \mathrm{C} ; \mathrm{CFV}, 0.2-0.8 \mathrm{~m} / \mathrm{s}$ & \multirow{2}{*}[49]{} \\
\hline & MF & Flat-sheet, MCE, $0.22,0.1$ and $0.025 \mu \mathrm{m}, 0.0209 \mathrm{~m}^{2}$ (Millipore Billerica, MA, USA) & TMP, $0.5-2.9$ bar; $\mathrm{T}, 20-40^{\circ} \mathrm{C} ; \mathrm{CFV}, 0.2-0.8 \mathrm{~m} / \mathrm{s}$ & \\
\hline Orange & UF & $\begin{array}{l}\text { Flat-sheet, PS, } 20 \mathrm{kDa}, 0.014 \mathrm{~m}^{2} \text { (PS 35, Sterlitech Corporation, Kent, WA, USA);Flat-sheet, PES, } 30 \mathrm{kDa}, 0.014 \mathrm{~m}^{2} \\
\text { (MK, Sterlitech Corporation, Kent, WA, USA) }\end{array}$ & $\mathrm{TMP}, 2$ bar, $\mathrm{Q}_{\mathrm{f}}, 228 \mathrm{~L} / \mathrm{h} ; \mathrm{T}, 27^{\circ} \mathrm{C}$ & [30] \\
\hline Orange & MF & Flat-sheet, MCE, $0.45 \mu \mathrm{m}, 0.0209 \mathrm{~m}^{2}$ (Millipore, Billerica, MA, USA) & TMP, $0.3-0.9$ bar; $\mathrm{CFV}, 0.3-1.2 \mathrm{~m} / \mathrm{s}$ & [50] \\
\hline Lemon & MF & Flat-sheet, PVDF (prepared in laboratory), $0.0069 \mathrm{~m}^{2}$ & $\mathrm{TMP}, 0.6$ bar; $\mathrm{CFV}, 1.0 \mathrm{~m} / \mathrm{s} ; \mathrm{T}, 20^{\circ} \mathrm{C}$ & [51] \\
\hline \multirow{2}{*}{ Passion fruit } & \multirow{2}{*}{ MF } & Tubular, $\alpha-\mathrm{Al}_{2} \mathrm{O}_{3} / \mathrm{TiO}_{2}, 0.3 \mu \mathrm{m}, 0.005 \mathrm{~m}^{2}$ & TMP, 0.5 bar; $\mathrm{Q}_{\mathrm{f}}, 500 \mathrm{~L} / \mathrm{h} ; \mathrm{T}, 25^{\circ} \mathrm{C}$ & \multirow[t]{2}{*}[52]{} \\
\hline & & Hollow fiber, PA, $0.3 \mu \mathrm{m}, 0.0158 \mathrm{~m}^{2}$ (PAM Membranas Seletivas LTDA, Brazil) & TMP 1.0 bar; $\mathrm{Q}_{\mathrm{f}}, 325 \mathrm{~L} / \mathrm{h} ; \mathrm{T}, 25^{\circ} \mathrm{C}$ & \\
\hline Passion fruit & MF & Hollow fiber, polieterimide, $0.40 \mu \mathrm{m}, 0.056 \mathrm{~m}^{2}$ (PAM Membranas Seletivas LTDA, Brazil) & TMP, 1.0 bar; $\mathrm{T}, 25^{\circ} \mathrm{C}$ & [53] \\
\hline Pineapple & MF & Hollow fiber, PS, $0.2 \mu \mathrm{m}, 0.011 \mathrm{~m}^{2}$ (Amersham Biosciences, Little Chalfont, UK) & $\mathrm{TMP}, 0.7 \mathrm{bar} ; \mathrm{CFV}, 3.4 \mathrm{~m} / \mathrm{s}, \mathrm{T}, 20 \pm 2{ }^{\circ} \mathrm{C}$ & [35] \\
\hline Pineapple & MF & Hollow fiber, PS, $0.2 \mu \mathrm{m}, 0.011 \mathrm{~m}^{2}$ (Amersham Biosciences, Little Chalfont, UK)) & TMP, 1.0 bar; $\mathrm{CFV}, 1.2 \mathrm{~m} / \mathrm{s} ; \mathrm{T}, 20 \pm 2{ }^{\circ} \mathrm{C}$ & [54] \\
\hline \multirow{2}{*}{ Pineapple } & UF & Tubular, $\alpha-\mathrm{Al}_{2} \mathrm{O}_{3} / \mathrm{TiO}_{2}, 0.01 \mu \mathrm{m}, 0.005 \mathrm{~m}^{2}$ & TMP, $2.0-6.0$ bar; $\mathrm{CFV}, 4.17 \mathrm{~m} / \mathrm{s} ; \mathrm{T}, 30-50^{\circ} \mathrm{C}$ & \multirow{2}{*}{ [55] } \\
\hline & & Hollow fiber, PS, $100 \mathrm{kDa}, 0.12 \mathrm{~m}^{2}$ (A/G Technology Corporation, Needham, MA, USA) & TMP, $0.2-2.0 \mathrm{bar} ; \mathrm{CFV}, 1.19 \mathrm{~m} / \mathrm{s} ; \mathrm{T}, 20-40^{\circ} \mathrm{C}$ & \\
\hline
\end{tabular}


Table 2. Cont.

\begin{tabular}{|c|c|c|c|c|}
\hline Fruit Juice & Process & Membrane Type & Operating Conditions & Ref. \\
\hline Pomegranate & MF & Flat-sheet, PVDF, $0.22 \mu \mathrm{m}$ and $0.45 \mu \mathrm{m}, 137.5044 \times 10^{-4} \mathrm{~m}^{2}$ (Millipore, Billerica, MA, USA) & TMP, 0.5 bar; $\mathrm{T}, 25^{\circ} \mathrm{C}$ & [56] \\
\hline \multirow{2}{*}{ Pomegranate } & MF & Hollow fiber, PVDF (prepared in laboratory), $0.13 \mu \mathrm{m}$ & TMP, 0.6 bar; $\mathrm{Q}_{\mathrm{f}}, 30 \mathrm{~L} / \mathrm{h} ; \mathrm{T}, 25^{\circ} \mathrm{C}$ & \multirow{2}{*}{ [37] } \\
\hline & MF & Hollow fiber, PS (prepared in laboratory), $0.13 \mu \mathrm{m}$ & TMP, 0.6 bar; $\mathrm{Q}_{\mathrm{f}}, 30 \mathrm{~L} / \mathrm{h} ; \mathrm{T}, 25^{\circ} \mathrm{C}$ & \\
\hline Pomegranate & UF & Hollow fiber, cellulose triacetate, $150 \mathrm{kDa}, 0.26 \mathrm{~m}^{2}$ (FUC 1582, Microdyn-Nadir, Wiesbaden, Germany) & TMP, 0.6 bar, $\mathrm{Q}_{\mathrm{f}}, 400 \mathrm{~L} / \mathrm{h} ; \mathrm{T}, 25^{\circ} \mathrm{C}$ & [57] \\
\hline Pomegranate & MF & Flat-sheet, MCE, $0.45 \mu \mathrm{m}, 78 \mathrm{~cm}^{2}$ (Millipore, Billerica, MA, USA) & Ultrasonic treatment; TMP, 0.5 bar; $\mathrm{Q}_{\mathrm{f}}, 17 \mathrm{~mL} / \mathrm{s}$ & [58] \\
\hline \multirow{2}{*}{ Pomegranate } & MF & Flat-sheet, MCE, $0.22 \mu \mathrm{m}, 0.0209 \mathrm{~m}^{2}$ (Millipore, Billerica, MA, USA) & Not reported & \multirow{2}{*}{ [59] } \\
\hline & UF & Flat-sheet, MCE, $0.025 \mu \mathrm{m}, 0.0209 \mathrm{~m}^{2}$ (Millipore, Billerica, MA, USA) & Not reported & \\
\hline Pomegranate & UF & Flat-sheet, PVDF, $30 \mathrm{kDa}, 0.0155 \mathrm{~m}^{2}$ (GE Osmonics, Minnetonka, MN, USA) & $\mathrm{TMP}, 3$ bar; $\mathrm{Q}_{\mathrm{f}}, 700 \mathrm{~L} / \mathrm{h} ; \mathrm{T}, 25 \pm 1^{\circ} \mathrm{C}$ & [60] \\
\hline Watermelon & MF & Flat-sheet, CA, $0.2 \mu \mathrm{m}, 15 \mathrm{~cm}^{2}$ (Sartorious India Ltd., Kolkata, India) & $\begin{array}{l}\text { TMP, } 1.36,2.04 \text { and } 2.76 \text { bar; stirring speeds, } 1200,1400 \\
\text { and } 1600 \mathrm{rpm} ; \mathrm{T}, 30 \pm 2{ }^{\circ} \mathrm{C}\end{array}$ & {$[61]$} \\
\hline Apple & UF & Tubular, $\mathrm{ZrO}_{2} / \mathrm{TiO}_{2}, 300,50,30 \mathrm{kDa}, 42.4 \mathrm{~cm}^{2}$ (Carbosep M8, M9 and M7, Tech-Sep, Miribel, France) & TMP, $1-4$ bar; $\mathrm{Q}_{\mathrm{f}}, 100-900 \mathrm{~mL} / \mathrm{min} ; \mathrm{T}, 20-55^{\circ} \mathrm{C}$ & [62] \\
\hline Apple & UF & Flat-sheet, oxygen plasma modified PS, $0.0140 \mathrm{~m}^{2}$ & TMP, 2.5 bar; $Q_{f}, 210 \mathrm{~L} / \mathrm{h}$ & [63] \\
\hline \multirow{3}{*}{ Apple } & \multirow{3}{*}{ UF } & Flat-sheet, PS, $100 \mathrm{kDa}, 0.0140 \mathrm{~m}^{2}$ (US100, Microdyn-Nadir, Wiesbaden, Germany) & \multirow{3}{*}{ TMP, 2.5 bar; $\mathrm{Q}_{\mathrm{f}}, 210 \mathrm{~L} / \mathrm{h} ; \mathrm{T}, 25 \pm 1^{\circ} \mathrm{C}$} & \multirow{3}{*}[64]{} \\
\hline & & Flat-sheet, PES, $50 \mathrm{kDa}, 0.0140 \mathrm{~m}^{2}$ (UH050, Microdyn-Nadir, Wiesbaden, Germany) & & \\
\hline & & Flat-sheet, RC, $30 \mathrm{kDa}, 0.0140 \mathrm{~m}^{2}$ (UC30, Microdyn-Nadir, Wiesbaden, Germany) & & \\
\hline \multirow{3}{*}{ Rasberry } & UF & Hollow fiber, PS, $30 \mathrm{kDa}, 1.8 \mathrm{~m}^{2}$ (Ultraflux ${ }^{\circledR} \mathrm{AV}$ 1000S, Fresenius Medical Care, Germany) & TMP, 1 bar; $\mathrm{Q}_{\mathrm{f}}, 1 \mathrm{~L} / \mathrm{min} ; \mathrm{T}, 22^{\circ} \mathrm{C}$ & \multirow{3}{*}{ [65] } \\
\hline & UF & Multitubular, $\mathrm{ZrO}_{2} / \mathrm{TiO}_{2}, 300,50,30 \mathrm{kDa}, 42.4 \mathrm{~cm}^{2}$ (Carbosep M8, M9 and M7, Tech-Sep, Miribel, France) & TMP, 1 bar; $\mathrm{Q}_{\mathrm{f}}, 1 \mathrm{~L} / \mathrm{min} ; \mathrm{T}, 22^{\circ} \mathrm{C}$ & \\
\hline & MF & Multitubular, $0.2 \mu \mathrm{m}, 644 \mathrm{~cm}^{2}$ (Kerasep W5, Tech-Sep, Miribel, France) & TMP, $0.5-3$ bar; $\mathrm{T}, 22-25^{\circ} \mathrm{C}$ & \\
\hline
\end{tabular}

Legend: MF, microfiltration; UF, ultrafiltration; PS, polysulphone; PES, polyethersulphone; PVDF, polyvinylidene fluoride; PAN, polyacrylonitrile; cellulose acetate, CA; RC, regenerated cellulose; $\mathrm{MCE}$, mixed cellulose ester; $\mathrm{TMP}$, transmembrane pressure; $\mathrm{Q}_{\mathrm{f}}$, feed flowrate; $\mathrm{CFV}$, cross-flow velocity; $\mathrm{T}$, temperature) 


\section{Membrane Fouling}

Despite the enormous benefits of MF and UF in the clarification of fruit juices, a major limiting factor that affect the performance of these operations is the decline of permeate flux with time. This phenomenon is caused by the accumulation of macromolecular or colloidal species (such as pectins and proteins) on the membrane surface (concentration polarization and gel layer) or by physico-chemical interactions with the membrane such as adsorption on the membrane pore walls and pore plugging (membrane fouling) [33,66]. Membrane fouling decreases not only permeate flux, but affect also, membrane longevity; therefore, it is a key factor affecting the economic and commercial viability of a membrane system [67]. Several approaches have been proposed to minimize membrane fouling mechanisms including the optimization of operating conditions, the pretreatment of the feed solution, membrane surface modification and the selection of appropriate membranes (in terms of molecular weight cut-off, morphology, and hydrophobicity/hydrophilicity).

The use of high shear stress at the membrane surface is a common feature to reduce particle deposition on the membrane. At this purpose several dynamic shear-enhanced filtration modules, which create a high shear rate on the membrane by using a rotating disk, or by rotating or vibrating the membranes are commercially available [68]. However, high permeate flux resulting from high shear can build up a cake layer because of additional convective transport of particles towards the membrane. In addition, this approach is highly energy consuming due to the intensive pumping required to circulate the juice at high velocities [69]. Therefore, the identification of optimum permeate flux (or TMP) is a critical issue in high-shear membrane filtration systems. Several flux concepts have been proposed to drive permeate flux selection, including limiting, critical, sustainable and threshold fluxes [70,71].

Permeate flux increases with the TMP, but the relation between them is only linear when the feed is pure water. At the higher pressure, the flux becomes independent of the pressure the system being in the mass-transfer-controlled region. According to the gel polarization model, the existence of a limiting flux is related to the concentration polarization phenomenon that arises as the feed solution is convected towards the membrane where the separation of suspended and soluble solids from the bulk solution takes place. The formation of a viscous and gelatinous-type layer is responsible for an additional resistance to the permeate flux in addition to that of the membrane [42,72].

Cassano et al. [73] investigated the effects of TMP and CFV on permeate flux, membrane fouling and quality of pomegranate juice clarified with modified poly(ether ether ketone) (PEEK-WC) and PS hollow fiber membranes prepared in laboratory. For both investigated membranes an increase of axial velocities reduced concentration polarization, enhanced the mass transfer coefficient and increased the steady-state permeate flux. However, an increase in pressure was not efficient in terms of flux improvement, for both selected membranes, due to the thickening or compression of the deposited layer onto the membrane surface and adsorption in the membrane pores. A limiting flux was reached when the TMP was increased up to a specific value; after that any further increase determined no significant increase of the permeate flux. By comparing the investigated membranes, PS membranes exhibited higher productivity, lower indexing of fouling and lower rejection towards biologically active compounds (flavonoids and total phenols) in comparison to PEEK-WC membranes (Table 3). Therefore, PS membranes were more appropriate for preserving the antioxidant properties and quality in the clarification of pomegranate juice.

Table 3. Physico-chemical characteristics of fresh and clarified pomegranate juice with PEEK-WC and PS membranes.

\begin{tabular}{cccccc}
\hline $\begin{array}{c}\text { Membrane } \\
\text { Type }\end{array}$ & Sample & $\begin{array}{c}\text { Polyphenols } \\
(\mathbf{g} / \mathbf{L})\end{array}$ & $\begin{array}{c}\text { Flavonoids } \\
(\mathbf{m g} / \mathbf{L})\end{array}$ & $\begin{array}{c}\text { Total Soluble Solids } \\
\left({ }^{\circ} \mathbf{B r i x}\right)\end{array}$ & $\begin{array}{c}\text { Suspended Solids } \\
(\% \mathbf{w} / \mathbf{w})\end{array}$ \\
\hline \multirow{2}{*}{ PEEKWC } & Feed & $1.576 \pm 0.03$ & $708 \pm 14.1$ & $16.0 \pm 0.10$ & $4.9 \pm 0.09$ \\
& Permeate & $1.062 \pm 0.02$ & $471 \pm 9.4$ & $15.4 \pm 0.25$ & n.d. \\
\hline \multirow{2}{*}{ PS } & Feed & $1.571 \pm 0.03$ & $741 \pm 14.8$ & $16.0 \pm 0.28$ & $4.9 \pm 0.09$ \\
& Permeate & $1.177 \pm 0.02$ & $562 \pm 11.2$ & $15.4 \pm 0.09$ & n.d. \\
\hline
\end{tabular}


Critical flux is defined as being the flux below which TMP remains strictly constant. Critical flux is generally low and its determination is time consuming limiting its industrial application. On the other hand, the concept of threshold flux, defined as the flux at which the rate of fouling increases significantly, is more applicable since it requires less time for its determination and generally matches with acceptable value of fluxes.

Laorko et al. [74] studied the effect of cross flow velocity (CFV) and gas sparging on critical flux, limiting flux, and quality during clarification of pineapple juice with a $0.2 \mu \mathrm{m}$ hollow fiber microfiltration membrane. Results showed that the critical and limiting flux increased as the CFV or shear stress number increased. The use of gas sparging led to a remarkable improvement in both the critical and limiting flux but it was more effective at the lower CFV (1.5 m/s), compared to those at higher CFV (2.0 and $2.5 \mathrm{~m} / \mathrm{s}$ ). The use of gas sparging, permitted also the reduction of reversible fouling and external irreversible fouling rather than internal irreversible fouling. In addition, CFV and gas sparging did not affect the physicochemical properties of clarified juice: the content of total polyphenols, total soluble solids and antioxidant capacity were preserved during the MF process. According with Authors, the use of gas sparging at low CFV, is an effective method for fouling reduction and flux enhancement preserving at the same time, the quality of the juice.

Several mathematical models have been proposed to analyze and predict the flux decline behavior during filtration of fruit juices. Empirical mechanistic models are based on a modified form of the equation developed by Hérmia for non-Newtonian fluids [75]:

$$
\frac{d^{2} t}{d V^{2}}=\beta\left(\frac{d t}{d V}\right)^{n}
$$

where $V$ is the cumulative volume of filtrate, $t$ the time of operation and $\beta$ a constant.

Field et al. [76] modified classical constant pressure dead-end filtration equations incorporating the effects of external turbulence leading to a steady state flux. The flux decline for different fouling mechanisms is expressed as:

$$
\frac{d J}{d t^{2}}=-K\left(J-J^{*}\right) J^{(2-n)}
$$

where $J^{*}$ is the steady state flux, $t$ is time and $K$ is a constant whose dimensions depends on the values of $n$. $n$ is a general index which assumes different values depending on fouling mechanisms.

The various modes of pore blocking are a function of the solid/solute size and shape in relation to the membrane pore size distribution. In the complete pore blocking $(n=2)$ it is assumed that particles are larger than pore size and a complete pore obstruction is obtained. the intermediate pore blocking $(n=1)$ is a dynamic situation in which particles may bridge a pore by obstructing the entrance but not completely blocking it. In standard pore blocking $\left(n=1.5 ; J^{*}=0\right)$ particles are much less than the membrane pore diameter so can enter the pores reducing the pore volume. The cake filtration $(n=0)$ occurs when particles are larger than the membrane pores diameter and a cake layer is formed on the membrane surface (Figure 4).

These blocking models have been used to analyze the decline in permeate flux observed in the MF and UF of several fruit juices including kiwifruit [34,46], pomegranate [77], red plum [49], orange [48,50], watermelon [61] tomato [78] and passion fruit [53] juices.

Under selected operating conditions of TMP and temperature, the fouling mechanism in the UF of blood orange juice evolved from a partial to a complete pore blocking condition in dependence of the axial velocity [48]. The cake formation was the dominant mechanism in the clarification of pomegranate juice $[50,77]$ and watermelon juice [61] with MF membranes. Similar results were found in the UF of kiwifruit juice with a cellulose acetate membrane of $30 \mathrm{kDa}$ [34]. A cake filtration mechanism resulted also to control the UF of pineapple juice with hollow fiber membranes; on the other hand, a pore blocking fouling mechanism was predominant in ceramic tubular membranes [55]. 
(a)

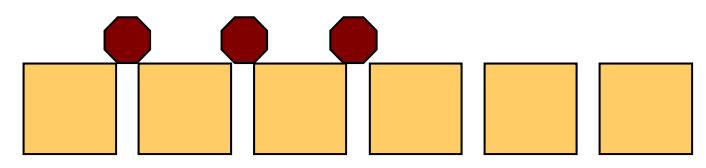

(b)

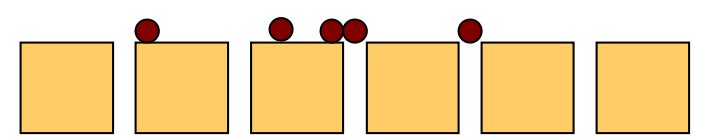

(c)

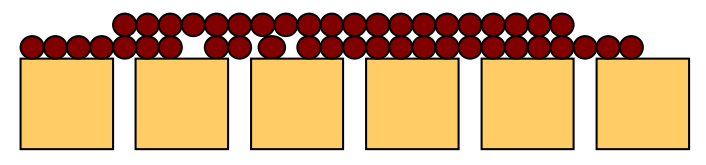

(d)

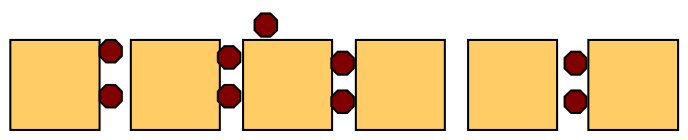

Figure 4. Scheme of fouling mechanism: complete pore blocking (a); partial pore blocking (b); cake filtration (c); internal pore blocking (d).

Membrane fouling can be also related to the flux decline resulting from an increase in flow resistances according to the resistance in series model $[79,80]$. According to this model the permeate flux $\left(J_{p}\right)$ for is usually written in terms of TMP and total resistance:

$$
J=\frac{T M P}{\mu R_{t}}
$$

where $J_{p}$ is the permeate flux (m/s), TMP is the transmembrane pressure $(\mathrm{kPa}), \mu$ the fluid viscosity (Pa s) and $R_{t}$ the total resistance $\left(\mathrm{m}^{-1}\right)$ expressed as:

$$
R_{t}=R_{m}+R_{p, r e}+R_{f p, i r}+R_{f}
$$

in which $R_{m}$ is the membrane resistance; $R_{p, r e}$ is the resistance of the reversible polarized layer consisting of the concentration polarization layer plus a precipitated gel resulting from the limit of solubility of macromolecules (it can be removed by rinsing with water at low flowrate); $R_{p, i r}$ is a semi-reversible polarized layer loosely bound to the fouling layer (it can be removed by rinsing with water at high flowrate); $R_{f}$ is the fouling resistance due to an irreversible adsorbed layer which can be removed only by chemical cleaning. All these resistances can be calculated by measuring the water flux through the membrane after cleaning with water and specific detergents. A schematic representation of the resistance-in-series model is shown in Figure 5.

According to the results obtained by Tasselli et al. [81] in the UF of kiwifruit juice with modified poly(ether ether ketone) (PEEK WC) hollow fibre membranes, $R_{m}$ controlled the permeate flux at TMP values lower than $0.3 \mathrm{bar}$, while at higher TMP the permeate flux was controlled by $R_{f} . R_{f}$ was also the major resistance to the permeate flux over the whole range of flowrate investigated.

Nourbakhsh et al. [82] found that the total resistance decreased by about $45 \%$ when the feed velocity was increased during the clarification of red plum juice (a juice without colloid particles) with PVDF membranes due to change in cake resistance. In addition, an increasing of the juice temperature from 20 to $30{ }^{\circ} \mathrm{C}$ decreased the total fouling resistance by about $9 \%$ due to the decrease of irreversible and reversible fouling resistances. On the other hand, for watermelon juice (a juice containing colloid particles) the increasing of feed velocity led to an increase of the cake resistance. Mixed cellulose ester (MCE) membranes had a lower cake resistance compared to PVDF membrane due to their hydrophilic character. 


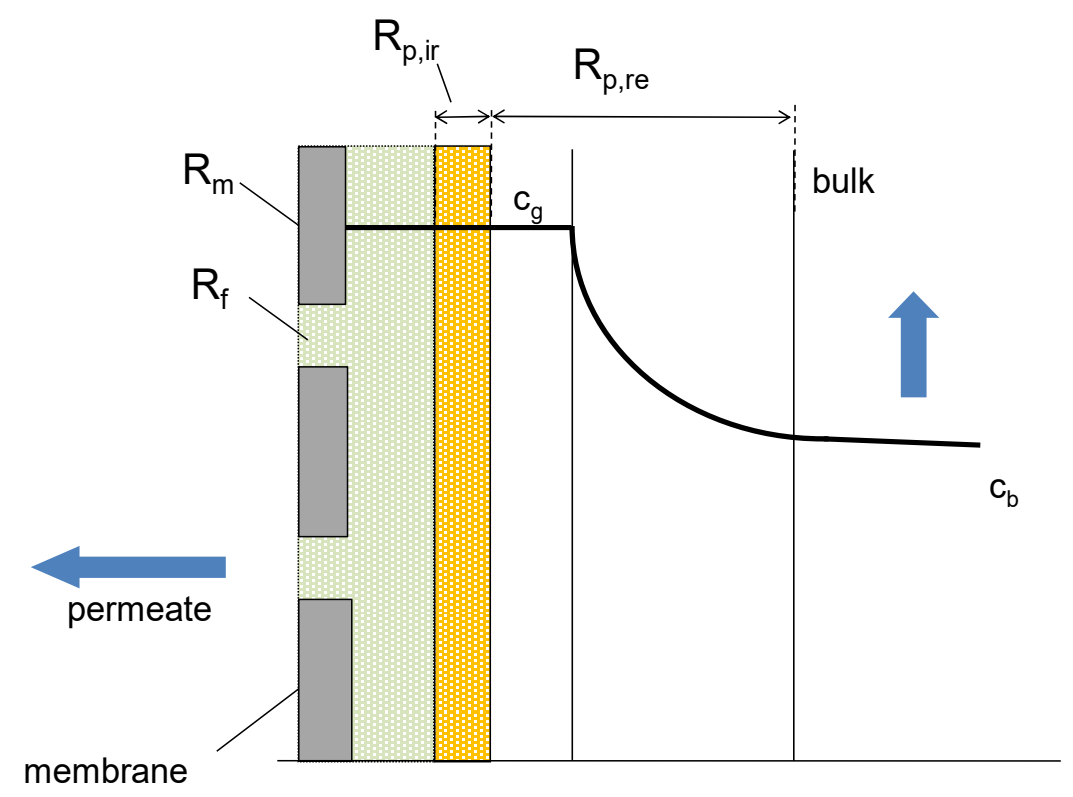

Figure 5. Schematic representation of the resistance-in-series model ( $R_{m}$, membrane resistance; $R_{f}$, fouling resistance; $R_{p, r e}$, resistance of the reversible polarized layer; $R_{p, i r}$, resistance of the semi-reversible polarized layer; $\mathrm{c}_{\mathrm{g}}$, gel concentration; $\mathrm{c}_{\mathrm{b}}$, bulk concentration).

A decrease of both total and fouling resistance with the increasing of feed flowrate was also observed by Vladisavljević et al. [62] in the clarification of depectinized apple juice with ceramic UF membranes. As expected, an increase in flowrate enhanced mass transfer coefficient and reduced concentration polarization and accumulation of retained solutes on the membrane surface. On the other hand, the fouling resistance increased with TMP. In particular, for small TMP values (e.g., 1 bar) the fouling resistance significantly decreased with increasing the feed flowrate, due to a higher rate of solute back-transfer. For higher TMP values (above 3 bar) the fouling resistance was virtually independent on the feed flowrate.

UF membranes with pore size of $0.025 \mu \mathrm{m}$ exhibited a greater fouling resistance when compared to MF membranes of $0.22 \mu \mathrm{m}$ in the clarification of pomegranate juice [59]. The evaluation of fouling resistance showed that the removal of large particles with the MF membrane decreased this resistance significantly. Permeate flux in MF resulted higher than that measured for UF membranes. Therefore, MF was recommended for juice clarification at reduced process cost in comparison to the UF process.

Recently, Gulec et al. [64] evaluated the effect of membrane pore size, roughness, and hydrophobicity on permeate flux and fouling of three different polymeric UF membranes used to clarify apple juice. The reversible fouling became the major resistance for membranes with greater pore size and hydrophobicity; on the other hand, cake formation was more prominent for membranes with narrower pore size. The quality of the juice was better preserved by using membranes with higher resistance to fouling.

Sharifanfar et al. [83] evaluated the effect of canal height (in the range $0.4-2 \mathrm{~cm}$ ) on the fouling mechanism in the clarification of pomegranate juice with a flat-sheet membrane having a pore size of $0.22 \mu \mathrm{m}$. Results indicated that both total and irreversible fouling resistances increased by increasing the canal height duo to the increase of the feed volume on the membrane surface.

As previously reported, in order to control and reduce membrane fouling, pre-treatments are usually used prior the clarification process, with the aim to decrease the content of macromolecules that are able to accumulate in the membrane surface or in the membrane pores. The pre-treatments include mainly the application of pectolic enzymes, fining agents, chitosan or centrifugation $[32,84]$. Rai et al. [85] studied the influence of different pre-treatment methods (fining by gelatine, bentonite, fining by bentonite followed by gelatine, centrifugation, enzymatic treatment followed by centrifugation, and enzymatic treatment followed by fining with bentonite) on the quality of mosambi juice clarified 
by UF. The combination of enzymatic treatment and subsequent adsorption with bentonite produced a clear juice with high quality and the highest permeate flux.

A combination of centrifugation, clarification with chitosan and enzymatic treatment, before passion juice MF and its influence on the physical-chemical characteristics of the clarified juice was investigated by Domingues et al. [53]. The addition of chitosan or enzyme reduced the viscosity of the passion juice. All the proposed pre-treatments presented a positive effect on the permeate flux, although the highest values were obtained with chitosan. The pre-treatment did not affect the quality of the clarified juice, except for the absence of total soluble solids. The MF process allowed to reduce the turbidity of the passion juice producing a clear juice. An influence of the applied pre-treatment on membrane fouling, was observed. In particular, centrifugation and enzymatic pre-treatments showed cake formation as major limiting factor, while internal pore blocking was dominant during the MF of the juice pretreated with chitosan. Therefore, the pre-treament with chitosan allowed to remove large particles minimizing the cake and gel layer formation during the MF of passion fruit juice.

Bagci [60] evaluated the effects of various pre-clarification treatments utilizing gelatin, bentonite and polyvinyl polypyrrolidone (PVPP) on the performance of the UF membranes in the clarification of pomegranate juice. A combination of PVPP and bentonite resulted the best pre-clarification treatment to enhance the permeate flux and improve the clarity of the juice. Quality attributes of pomegranate juice were well preserved in comparison to conventional clarification procedures.

The use of ultrasounds has been also investigated to reduce membrane fouling in the clarification of fruit juices. Aghdam et al. [86] evaluated the effect of ultrasonic treatment on different fouling mechanisms during clarification of pomegranate juice with a MCE membrane with a pore size of 0.45 $\mu \mathrm{m}$. Results showed that cake formation is a dominant mechanism in both ultrasonic treatment and non-ultrasonic one; however, the intensity of cake formation in the absence of ultrasound waves was much more than its value in the presence of ultrasound. Permeate flux increased with the ultrasonic treatment; on the other hand, the ultrasonic treatment reduced the antioxidant activity and total soluble solids of the juice as it increased the feed temperature [58].

Characteristics of membrane material, including surface charge, hydrophobicity and roughness, play a key role on membrane fouling of MF and UF membranes. Hydrophilic membranes exhibit lower fouling tendency due to lower adsorption of organic particles [87]. Membranes with smoother surfaces also decrease adsorption phenomenon, limiting cake formation [88]. The modification of surface structure of hydrophobic polymeric membranes through chemical and physical treatments is an interesting approach to reduce membrane fouling of UF membranes.

The surface modification technique of UF membranes by gas plasma treatment has been recently investigated by Gulec et al. [63]. Raw apple juice was clarified through commercial PS membranes modified by low-pressure oxygen plasma treatment. The plasma action resulted in higher hydrophilicity and lower surface roughness and, consequently, in improved antifouling behavior in comparison to untreated membranes. The long-term gradual flux decline was still predominant in the treatment with plasma treated membranes but the rapid decrease in the initial permeate flux was successfully prevented by plasma action due to the charge repulsion between the modified membrane and the foulant particles.

Recently, the use of immersed membranes has been investigated as an interesting alternative to cross-flow filtration systems for the clarification of fruit-based suspensions [89]. In this configuration, plane or hollow fiber membranes are immersed in the suspension and the filtration is generally ensured by permeate suction at constant flux. Optimal permeate fluxes of hollow fiber immersed MF membranes in the treatment of grape juice were found to be around $5-7 \mathrm{~L} / \mathrm{m}^{2} \mathrm{~h}$. These values resulted lower than those measured for cross-flow filtration; on the other hand, the quality of the clarified juice was similar to that of conventional cross-flow filtration. Thanks to their compactness, easy handling and mobility, low investment and operational costs, immersed membranes could be a viable approach for small production units of fruit juices. 


\section{Fruit Juice Concentration}

Concentration of fruit juices includes a series of advantages such as weight and volume reduction, with a consequent reduction of packaging, transport, handling and storage costs. An enhancement of the product stability due to the reduction of the water activity is also reached. Finally, the concentration step allows a better product preparation for a final drying treatment. Most of the marketed juices are produced from fresh juices concentrated by thermal evaporation up to $90{ }^{\circ} \mathrm{C}$. This process is characterized by several drawbacks such as large amount of energy for the removal of water, foam formation, loss of aroma and antioxidant compounds, induction of cooked odor due to furfural formation and coloring due to Maillard reactions [90,91]. Membrane processes, including NF, RO, MD and OD allow to concentrate juices at mild low-temperature conditions so reducing energy consumption and preserving aroma, nutritional and bioactive compounds. These processes can be combined with other membrane operations such as, UF, MF and PV for designing fully integrated membrane systems for producing high quality juices through clarification, concentration and aroma recovery steps within the process intensification strategy [15]. This strategy aims at redesign the conventional industrial production processes through the implementation of new technologies leading to drastic improvements in manufacturing and processing, substantially decreasing the equipment-size/production-capacity ratio, energy consumption and waste production and resulting in cheaper and more sustainable solutions [92].

\subsection{Nanofiltration}

The NF process offers specific advantages over $\mathrm{RO}$ in fruit juice concentration mainly due to the lower operating pressures of the process which allow to reduce the energy consumption (21\% lower than $\mathrm{RO}$ ) and improve the juice quality which can be damaged when high pressures are used. NF membranes in tubular and flat-sheet configuration were used to concentrate both apple and pear juices at low operating pressures [93]. Among the selected membranes, the Desal-5DK (from GE Osmonics, Minnetonka, MN, USA), in flat-sheet configuration, produced higher permeate fluxes and higher concentration degree (1.06 against 1.01 of MPT-34 membrane). The decrease in permeate flux resulted significantly greater in juice solutions than in fructose solutions due to the complex composition of juices.

Average permeate fluxes of about $20 \mathrm{~L} / \mathrm{m}^{2} \mathrm{~h}$ were obtained in the concentration of blackcurrant juice with a NF flat-sheet membrane in selected operating conditions (pressure, 20 bar; temperature, $30^{\circ} \mathrm{C}$; feed flowrate, $400 \mathrm{~L} / \mathrm{h}$ ). At VCR of 2.23 the retention of total extract was of $96.72 \%$ [94].

Arend et al. [95] evaluated the performance of a PVDF ND membrane of 150-300 Da (from GE Osmonics) in the concentration of bioactive compounds from microfiltered and natural strawberry juice. Higher permeate fluxes $\left(4.0 \mathrm{~L} / \mathrm{m}^{2} \mathrm{~h}\right)$ were measured for the untreated juice in comparison to the clarified juice $\left(3.0 \mathrm{~L} / \mathrm{m}^{2} \mathrm{~h}\right)$; however, a less pronounced reduction of permeate flux was observed for the microfiltered juice due to the absence of suspended solids. The antioxidant activity of concentrated samples at VCR of 2.0 presented an increase of $99 \%$ and $51 \%$ for the untreated and clarified juice, respectively.

The NF process is a viable approach to increase the sugar content of grape must in wine production as alternative to other subtractive techniques including $\mathrm{RO}$ and cryoconcentration. Indeed, the use of $\mathrm{RO}$ membranes is characterized by some drawbacks such as high energy consumption and severe membrane fouling as well as the concentration of natural components of must other than sugars (i.e., malic acid) that may emphasize the lack of wine sensory balance.

Commercial NF membranes used for grape must concentration and fractionation were characterized by permeation fluxes from 8 to $80 \mathrm{~kg} / \mathrm{m}^{2} \mathrm{~h}$ upon the variation of the membrane characteristics and the operating conditions with a preferential permeation of the organic acids with respect to sugars [96]. Similarly, polyamide NF membranes in spiral-wound configuration (DK and DS, from GE Osmonics, Minnetonka, MN, USA) provided a high rejection of sugars (range 77-97\%) and polyphenols (range $70-94 \%$ ), whereas the malic acid was retained to a low extent (range 2-14\%). A two-stage NF process of grape must removed a permeate volume of $14 \%$, thus allowed concentration of the sugars, i.e., 
the potential alcohol, to ca. 16\%. [97]. Permeate flux of spiral-wound NF membranes (VINOPRO 4040C-30D and NF270-4040, both from GE Osmonics, Minnetonka, MN, USA) resulted higher than those observed for $\mathrm{RO}$ membranes in the concentration of musts deriving from red and white grapes [98]. An increase of about 10 and $9 \%$ in dry extract was observed in wines obtained by RO and NF-treated musts, respectively, suggesting an increase of wine body and roundness.

\subsection{Reverse Osmosis}

The advantages of RO over conventional concentration techniques are in terms of low thermal damage of the product, reduction of energy consumption and lower capital investments as the process is carried out at low temperatures and it does not involve phase change for water removal. The first application of $\mathrm{RO}$ in fruit juice processing was developed for the concentration of orange juice with the use of PA composite membranes showing an excellent retention of juice constituents including sugars, acids and aromatic compounds [99]. The preferential sorption-capillary flow model was used to predict the rejection of the most hydrophilic aroma compounds (isopentyl acetate, isobutanol, isopentanol and ethyl-2-methyl butanoate) in the concentration of apple juice with these membranes; higher rejections than the experimental ones were predicted for the least hydrophilic compounds (hexanal, hexanol, hexyl acetate, ethyl butanoate and butanol) [100].

The concentration of fruit juices by $\mathrm{RO}$ is affected by operating parameters including feed pressure, temperature and flowrate. Permeate fluxes generally increase by increasing TMP (at a constant concentration). High permeate fluxes can be obtained at high feed velocities; on the other hand, permeate flux decrease by increasing the concentration of soluble solids due to the increase of juice osmotic pressure and viscosity [101]. For apple juice concentration, the average processing capacity increases of about $3-4 \%$ for every $1{ }^{\circ} \mathrm{C}$ increase at operating temperature between 20 and $60{ }^{\circ} \mathrm{C}$ [102].

Jesus et al. [103] compared the sensory characteristics of orange juice concentrated by RO (in a plate and frame pilot plant with $0.72 \mathrm{~m}^{2}$ of filtration area) and thermal evaporation. The RO concentrate had a more acid taste but it best preserved the characteristic aroma of the juice, differing significantly from the juice concentrated by thermal evaporation. Initial permeate flux values in $\mathrm{RO}$ were of about $28 \mathrm{~L} / \mathrm{m}^{2} \mathrm{~h}$ at a TMP of 60 bar. In these conditions the vitamin $\mathrm{C}$ content of the single-strength juice at $8.2^{\circ}$ Brix increased from $29.3 \mathrm{mg}$ ascorbic acid/100 $\mathrm{g}$ (single strength juice) to $101.1 \mathrm{mg} / 100 \mathrm{~g}$ in the concentrated juice (final concentration $35.7^{\circ}$ Brix).

Echavarría et al. [104] applied RO preceded by enzymatic treatment and ultrafiltration to concentrate peach, pear, apple and mandarin juices in a pilot plan scale. Permeate flux in RO decreased as the concentration factor increased, due to concentration polarization and fouling, in addition to the increase of osmotic pressure and the viscosity of the juice. Higher TMP values allowed a faster concentration of the clarified juices as well as higher concentration levels. The highest total soluble solids content of 30.5 Brix was reached for the peach juice at a TMP of 40 bar. Both TMP and cross-flow velocity showed a positive effect on the permeate flux.

In spite of the high selectivity and solute retention capacity of RO membranes, this process has a significant drawback. The osmotic pressure and viscosity of fruit juices increase rapidly with the increasing of the sugar concentration. For cellulosic and non-cellulosic membranes, the most efficient flux and solute recovery were obtained at a concentration lower than $30^{\circ}$ Brix [99]. Therefore, in several applications $\mathrm{RO}$ has been employed as a pre-concentration step before a final concentration with other technologies such as freeze concentration, thermal evaporation, MD and OD. An integrated membrane process for producing concentrated apple juice including $\mathrm{RO}$ as preconcentration step was developed by Alvarez et al. [105]. The process involved a clarification step through an enzymatic membrane reactor, preconcentration by $\mathrm{RO}$, aroma compounds recovery by $\mathrm{PV}$ and final concentration up to $72{ }^{\circ}$ Brix by thermal evaporation. These operations were tested in both laboratory and pilot plant units. Permeate flow between 75 and $110 \mathrm{~L} / \mathrm{h}$ and concentrations of apple juice between 25.5 and $26.6^{\circ}$ Brix were obtained in the RO step and rejection of aroma compounds exceeded $90 \%$ for most of the considered compounds. On the basis of an economic evaluation of conventional and membrane-based processes, 
the total capital investment of the integrated membrane process resulted $14 \%$ lower than that of the conventional process. Total manufacturing costs decreased by $8 \%$ when concentrating the apple juice by membranes mainly because less energy is required to concentrate the juice. Net profit and return on investment were estimated to be about $16 \%$ and $34 \%$ higher than conventional ones, respectively.

\subsection{Membrane Distillation}

MD has received a great attention as technique for concentrating fruit juices since it can be carried out at atmospheric pressure and at a temperature which can be much lower than the boiling point of the feed solution. Evaporation fluxes are influenced by several parameters including membrane type, total soluble solids content and operating conditions (i.e., temperature and flowrate of both feed and distillate streams) [106].

PVDF membranes used for the concentration of orange juice showed a total rejection for total soluble solids, sugars and organic acids [107]. The reduction of vitamin C (of about $42.1 \%$ ) was associated with high temperature and oxidation. In addition, the best retention of volatile compounds for a given amount of water removal in MD was provided by membranes having an open fibrous structure rather than small pores.

MD resulted a viable method to concentrate black-currant juice up to a high solid content $\left(58.2^{\circ}\right.$ Brix) preventing the juice from deterioration [108]. Evaporation fluxes slowly decreased till the end of the process due to a decrease in the driving force and the Re number of the concentrate. Density, total acid content and anthocyanins increased proportionally to the increase of the TSS content.

Quist-Jensen et al. [109] evaluated the potential of DCMD for the concentration of clarified orange juice by using a laboratory bench plant equipped with two polypropylene hollow fiber membrane modules (ENKA MD-020-2N-CP, Microdyn-Nadir, Wiesbaden, Germany) having a nominal pore size of $0.2 \mu \mathrm{m}$ and a membrane surface area of $0.1 \mathrm{~m} 2$. The clarified juice was pumped through the fibre lumens side of the membrane module at a temperature of $24{ }^{\circ} \mathrm{C}$ while pure water was recirculated in the shell side, in a countercurrent mode, at a temperature of about $17^{\circ} \mathrm{C}$. The clarified juice, with an initial total soluble solids (TSS) content of about $9.5^{\circ}$ Brix, was concentrated up to $65^{\circ}$ Brix through a two-step DCMD process. The juice viscosity resulted almost constant in the pre-concentration step when the TSS content was raised from 9 to $24^{\circ}$ Brix. In this range the flux decay (from 0.6 to $0.4 \mathrm{~kg} / \mathrm{m}^{2} \mathrm{~h}$ ) was attributed to the inherent temperature polarization phenomena. A more rapid decline of the evaporation flux due to the strong increase in juice viscosity was observed in the second step confirming that at a higher TSS content the flux decay mainly depends on juice viscosity and, consequently, on juice concentration and temperature $[110,111]$. In addition, membrane fouling phenomena occur as a result of specific interactions between the membrane and sugars offering an additional resistance to mass transfer and heat transfer [112]. The content of phenolic compounds in the clarified juice was well preserved in both subsequent concentration steps. Accordingly, the final concentrated sample showed a TAA similar to that of the UF permeate, confirming the particular mildness of the treatment. Small crystals with a low coefficient of variation were detected in the concentrated juice at $65{ }^{\circ}$ Brix.

Evaporation flux of about $1 \mathrm{~kg} / \mathrm{m}^{2} \mathrm{~h}$ were obtained in the concentration of apple juice with a polypropylene hollow fiber membrane module (ENKA MD-020-2N-CP, Microdyn-Nadir, Wiesbaden, Germany) having a tube and shell configuration. The trans-membrane driving force decreased with increasing extra-fiber temperature but increased with higher feed and distillate flowrates in the intra- and extra-fiber volumes, respectively [113]. The juice viscosity at high concentration induced severe polarization phenomena. However, temperature polarization resulted higher than concentration polarization.

Sotoft et al. [114] proposed a conceptual process design for the concentration of blackcurrant juice and aroma recovery through a combination of membrane processes including VMD, for aroma recovery, and RO, NF and DCMD for water removal (Figure 6). The membrane area estimated for a production of 17,283 ton of concentrated juice per year was of $810 \mathrm{~m}^{2}$ for VMD, $4250 \mathrm{~m}^{2}$ for DCMD, $630 \mathrm{~m}^{2}$ for $\mathrm{RO}$ and $170 \mathrm{~m}^{2}$ for NF. The estimated production cost, about $0.40 € / \mathrm{kg}$ juice concentrate at $66^{\circ} \mathrm{Brix}$, resulted $43 \%$ lower than that of a conventional thermal evaporation if considering for 
membrane lifetime of one year. According to industrial sources, this cost is comparable to that of traditionally produced concentrates. If the membrane lifetime increases to 2 or 3 years the calculated production costs of the concentrate are reduced to 0.30 and $0.27 € / \mathrm{kg}$ juice concentrate, respectively.

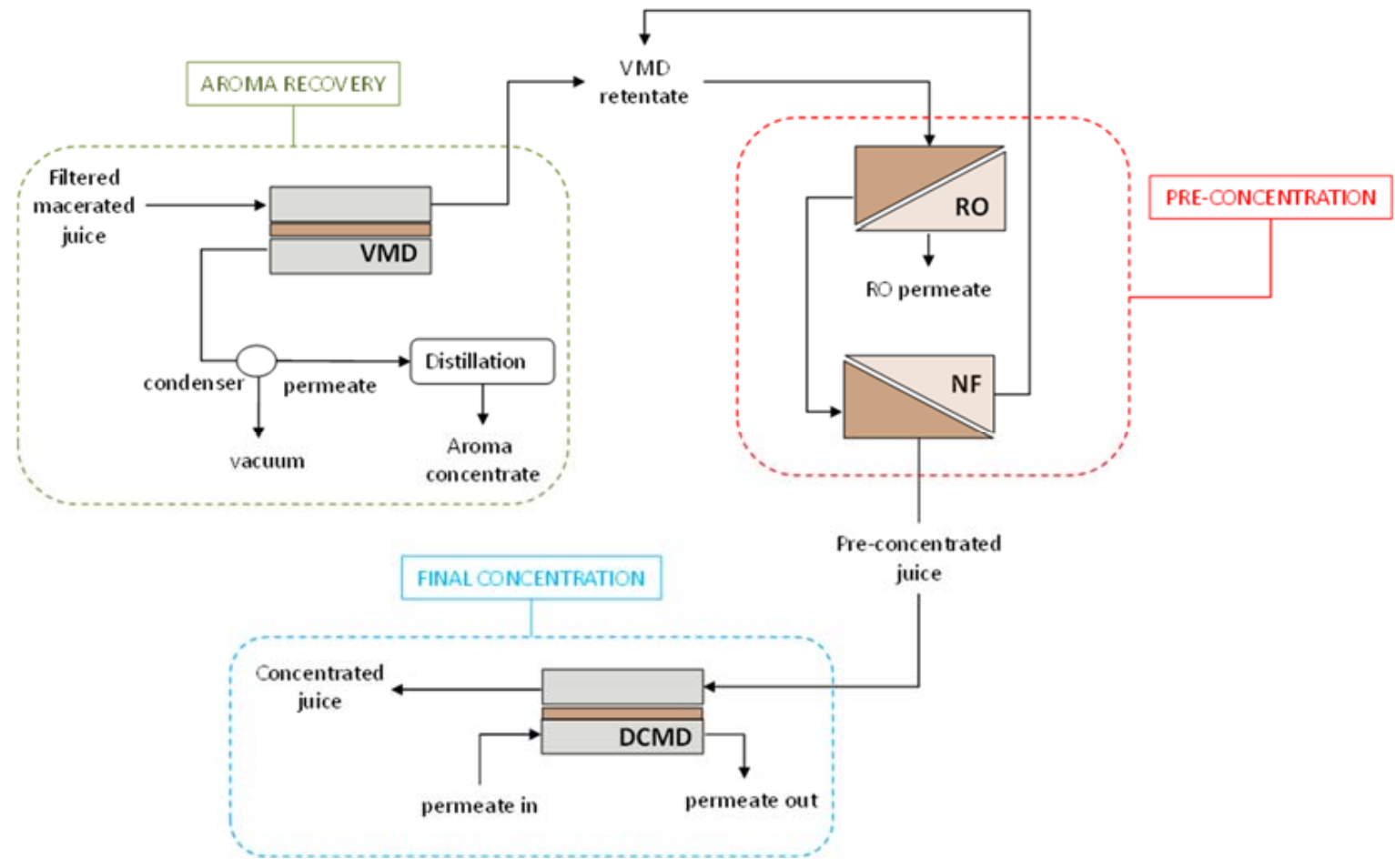

Figure 6. Process layout for aroma recovery and juice concentration based on membrane processes (adapted from [114]).

\subsection{Osmotic Distillation}

OD has attracted considerable interest for the concentration of fruit juices since it allows to reach high levels of total soluble solids (up to $65-70^{\circ}$ Brix) operating at low temperature and pressure, thereby maintaining original organoleptic and sensorial characteristics of the raw material. The process has been implemented on both laboratory and pilot scale for several fruit juices including kiwifruit $[115,116]$ pineapple [117-119], grape [120,121], passion fruit [111], noni [122], orange [123,124], apple [121,124], bergamot [125] and pomegranate juices [126,127]. In most of these applications the juice has been previously clarified due to the geometrical limitations of commercially available membranes and modules. At this purpose, the clarification of the raw juice with MF or UF membranes result in appreciable OD flux improvements due to the reduction in the viscosity of the concentrated juice-membrane boundary layer where the solute concentration is the highest [128].

The evaporation fluxes in OD depend strongly on the osmotic pressure difference between the stripping solution and the juice. Other operating factors which enhance the performance of the OD process are the use of higher temperature than ambient (to increase the driving force and decrease the juice viscosity) and improvement of the cell hydrodynamic conditions in the OD module [17]. The solute content of both stripping and feed solutions was identified as the most influencing variable on mass transfer in the concentration of sucrose solutions by OD [110].

The most well-known membrane module designed for OD is the Liqui-Cel membrane contactor manufactured by 3M (Charlotte, NC, USA; formerly Hoechst Celanese) containing macroporous PP hollow fibers with an average pore diameter of $0.2 \mu \mathrm{m}$. Figure 7 shows the performance of the module in the concentration of clarified pomegranate juice (recirculate in the shell side) at $25^{\circ} \mathrm{C}$ by using calcium chloride dehydrate as stripping solution (recirculated in the fiber lumen) [126]. 

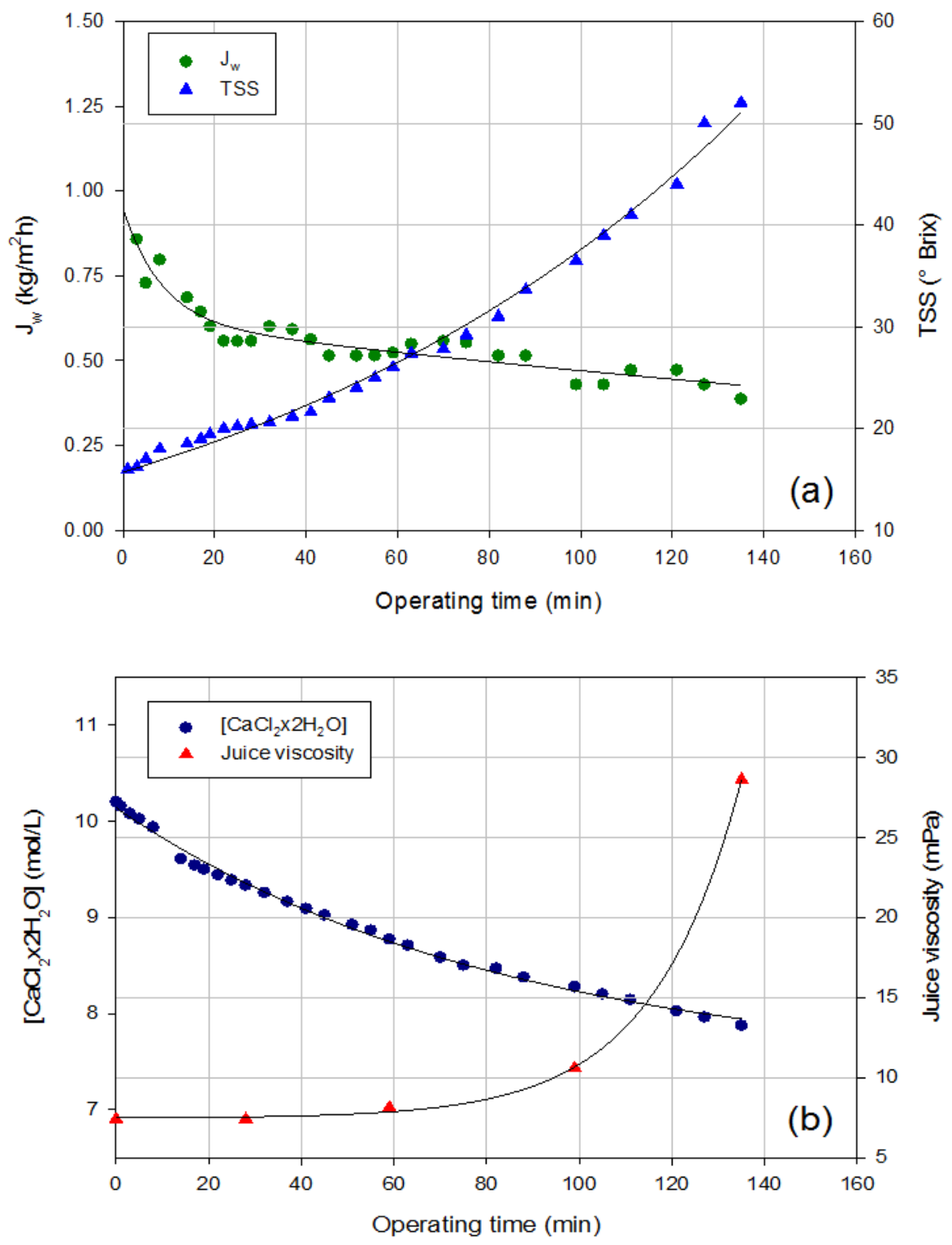

Figure 7. Concentration of pomegranate juice by OD. Time evolution of (a) evaporation flux and total soluble solids (TSS); (b) concentration of stripping solution and juice viscosity (adapted from [126]).

The initial evaporation flux, of about $0.85 \mathrm{~kg} / \mathrm{m}^{2} \mathrm{~h}$ decreased gradually up to a final value of $0.38 \mathrm{~kg} / \mathrm{m}^{2} \mathrm{~h}$ when the TSS content of the concentrated juice was $52.0^{\circ}$ Brix (Figure $7 \mathrm{a}$ ). The dilution of the brine solution led to a decrease in vapor pressure of the osmotic agent and, consequently, to the decrease of driving force for water transport from the juice through the membrane (Figure $7 \mathrm{~b}$ ); in addition, the increase in TSS content of the juice resulted in an exponential increase in juice viscosity contributed to determine a polarization effect leading to a lower driving force.

Pore blocking phenomena of PP hollow fiber membranes used to concentrate clarified pomegranate juice were identified by Rehman et al. [127]. Authors found also that the hydrophobicity of PVDF membranes declined by $29 \%$ after juice concentration, as opposed to $6 \%$ with PTFE membranes, indicating that these membranes are much prone to wetting [129]. Coating of hydrophobic hollow fiber PVDF membranes with chitosan provided protection against wetting and flavor loss in the OD process maintaining stable flux [130].

Rodrigues et al. [131] evaluated the performance (flux and concentration factor) of RO and OD in the concentration of camu-camu juice. RO allowed to reach a maximum TSS content $25^{\circ}$ Brix at a TMP 
of 60 bar and $22{ }^{\circ} \mathrm{C}$ with an average permeate flux of $50 \mathrm{~kg} / \mathrm{m}^{2} \mathrm{~h}$ and a loss of ascorbic acid of $8 \%$. High concentration levels ( $60^{\circ}$ Brix) were reached by OD with average evaporation fluxes of $10 \mathrm{~kg} / \mathrm{m}^{2} \mathrm{~h}$. Concentrated juice presented nutritional quality very similar to that of the original juice regarding vitamin C content (losses below 5\%).

Recently, Roozitalab et al. [132] evaluated the performance of OD in the concentration of pomegranate juice by using a nanofibrous polyether-block-amid (PEBA) membrane prepared by the electrospinning technique and calcium chloride dehydrate as stripping solution. The OD concentrate had better quality than the thermally evaporated product in terms of aroma and phenolic compounds retention. The economic analyses, based on the estimation of investment and operating costs (Table 4), revealed that both OD and thermal evaporation are economically feasible for the concentration of pomegranate juice. The profit of the OD process resulted lower than the evaporation due to the higher equipment costs of the OD process (a total membrane surface area of $328 \mathrm{~m}^{2}$ was estimated). Moreover, the break-even point of the OD process was higher than that of the evaporation process.

Table 4. Economic analyses of pomegranate juice concentration by OD and thermal evaporation [132].

\begin{tabular}{lll}
\hline \multicolumn{1}{c}{ Economic Index } & \multicolumn{1}{c}{ Osmotic Distillation } & \multicolumn{1}{c}{ Thermal Evaporation } \\
\hline Equipment costs $(\$)$ & 74,446 & 34,499 \\
Fixed costs (\$) & 481,057 & $221,378.0$ \\
Working capital $(\$)$ & $10,019,053$ & $9,920,708$ \\
Total investment costs (\$) & $10,572,276$ & $10,175,205$ \\
Production costs (\$) & $12,172,070$ & $11,901,000$ \\
Gross profit from operations (\$) & $61,499,774$ & $61,615,771$ \\
Payback period (Year) & 2 & 2 \\
Internal rate of return on investment (IRR) (\%) & 66.47 & 68.09 \\
Break-even point (\%) & 29.4 & 23.2 \\
\hline
\end{tabular}

Dincer et al. [133] compared the quality parameters of black mulberry juice concentrated by both OD and thermal evaporation after reconstitution with different storage times and temperatures. Heat-sensitive components of the OD concentrated juice were better preserved in comparison to the thermally concentrated juice. In addition, the tested quality parameters of the OD concentrate resulted still favorable during storage at low temperature. Phenolic compounds of cranberry juice were also well preserved during juice concentration by OD at temperatures between 30 and $40{ }^{\circ} \mathrm{C}$. [134]. Evaporation fluxes ranged between 0.25 and $1.21 \mathrm{~L} / \mathrm{m}^{2} \mathrm{~h}$. A mass transfer model was also proposed to predict the water transfer through the membrane obtaining an estimation of this value with a maximum deviation of $32 \%$.

PTFE membranes with pore size of 0.45 and $0.20 \mu \mathrm{m}$ produced higher evaporation fluxes (of the order of $2-3 \mathrm{~kg} / \mathrm{m}^{2} \mathrm{~h}$ ) and higher final juice concentrations (up to $23.4^{\circ}$ Brix) when compared to $0.10 \mu \mathrm{m}$ PP membranes in the concentration of cactus pear juice by OD [135]. PTFE membranes with different pore size $(0.20,0.45$ and $1.2 \mu \mathrm{m})$ were also used for the concentration of red grape juice. Experimental results indicated that membrane porosity did not affect the transmembrane water flux and the final concentration of the processed juice [136].

The use of OD as a direct process to concentrate fruit juices is difficult to implement at industrial scale, since the large amount of water present in the initial juice promotes a fast brine dilution, which negatively affects the productivity of the process. In this context, the coupling of RO and OD can be considered a promising alternative, since it results in products with similar solid content than those obtained by conventional methods (such as vacuum evaporation), with less pronounced effects on the juice's quality [137].

$\mathrm{RO}$ was used as a pre-concentration step to concentrate clarified orange and carrot juices up to 15-20 ${ }^{\circ}$ Brix before a final concentration by OD. A little decrease of the antioxidant activity of orange juice was observed in the $\mathrm{RO}$ process in comparison with the clarified juice, probably on account of the high pressure (50 bar) experienced by the juice during this treatment [138]. Anthocyanins were also 
slightly affected by the RO process, decreasing of about $23 \%$; on the contrary, no significant variations were observed for hydroxycinnamic acids and for flavanones, which appeared to be very stable under the selected operating conditions of the RO process [139].

Highly concentrated black currant juice was produced by a multi-step membrane process including $\mathrm{OD}$ as final concentration step on both laboratory and large scale [40]. On large scale the microfiltered and preconcentrated juice (by RO) was concentrated up to $63^{\circ}$ Brix at an average evaporation flux of $0.6 \mathrm{~kg} / \mathrm{m}^{2} \mathrm{~h}$. Its anthocyanin content was more than three times higher than that of the raw juice.

An integrated process for the production of high quality apple juice concentrate was proposed by Aguiar et al. [140]. The enzymatically treated juice was clarified by MF, preconcentrated by RO (up to $29^{\circ}$ Brix) and then concentrated by OD (up to $53^{\circ} \mathrm{Brix}$ ). The OD fluxes resulted significantly lower than those obtained in the RO process, ranging from $1.55 \mathrm{~L} / \mathrm{m}^{2} \mathrm{~h}$ to $0.01 \mathrm{~L} / \mathrm{m}^{2} \mathrm{~h}$. Reductions of phenolic compounds and antioxidant activity of $8 \%$ and $22 \%$, respectively, were detected in the OD concentrates due to the occurrence of oxidative reactions during the concentration process.

The industrial application of OD is still limited by the low productivity of the process and the management of the diluted stripping solution generated during the process. Membrane processes, including PV and OD, as well as atmospheric evaporation and direct contact evaporation with flue gas, have been proposed to regenerate spent solutions from the osmotic food dehydration [141-143]. However, this approach precludes the use of calcium chloride as the osmotic agent due to formation of calcium carbonate due to the presence of carbon dioxide in combustion gases. Recently, the use of potassium pyrophosphate has been proposed as alternative to the use of calcium chloride [144]. Orange juice was concentrated up to $27^{\circ}$ Brix without affecting its physicochemical characteristics. Losses of volatile compounds were no larger than $62 \%$, while $100 \%$ of the aroma compounds were lost during thermal concentration. Typical applications of $\mathrm{OD}$ in fruit juice concentration are summarized in Table 5 . 
Table 5. Concentration of fruit juices by osmotic distillation.

\begin{tabular}{|c|c|c|c|c|}
\hline Fruit Juice & Osmotic Agent & Membrane Type & Average Flux $\left(\mathrm{kg} / \mathrm{m}^{2} \mathrm{~h}\right)$ & Ref. \\
\hline Grape (clarified by UF) & $\mathrm{CaCl}_{2} 40 \% w / w$ & hollow fiber, PP (Liqui-Cel ${ }^{\circledR}$, Hoechst-Celanese Wiesbaden, Germany) & 2 & [128] \\
\hline Pineapple (clarified by MF) & $\mathrm{CaCl}_{2} 4.6 \mathrm{~m}$ & hollow fiber, PP & n.r. & [119] \\
\hline $\begin{array}{l}\text { Citrus and carrot (clarified by UF and } \\
\text { preconcentrated by RO) }\end{array}$ & $\mathrm{CaCl}_{2} \times 2 \mathrm{H}_{2} \mathrm{O} 60-66 \% w / w$ & $\begin{array}{l}\text { hollow fiber, PP (Liqui-Cel }{ }^{\circledR} \text { Extra-Flow } 2.5 \times 8 \text {-in. membrane contactor, Hoechst-Celanese, } \\
\text { Wiesbaden, Germany) }\end{array}$ & 0.8 (carrot juice); 0.8 (blood orange juice) & [138] \\
\hline Kiwifruit (clarified by UF) & $\mathrm{CaCl}_{2} \times 2 \mathrm{H}_{2} \mathrm{O} 60 \% w / w$ & $\begin{array}{l}\text { hollow fiber, PP (Liqui-Cel }{ }^{\circledR} \text { Extra-Flow } 2.5 \times 8 \text {-in. membrane contactor, Hoechst-Celanese, } \\
\text { Wiesbaden, Germany) }\end{array}$ & 0.5 & [116] \\
\hline Camu-camu (clarified by MF) & $\mathrm{CaCl}_{2} 4.0-5.2 \mathrm{M}$ & $\begin{array}{l}\text { plate and frame, thin PTFE layer sealed on a PP supporting net (TF200 Pall-Gelman, } \\
\text { Washington, NY, USA) }\end{array}$ & 10 & [131] \\
\hline Grape & Glycerol $70 \% w / w$ & $\begin{array}{l}\text { plate and frame, thin PTFE layer sealed on a PP supporting net (Pall-Gelman, Washington, } \\
\text { NY, USA) }\end{array}$ & 1.9 & [120] \\
\hline Melon (clarified by MF) & $\mathrm{CaCl}_{2} 5.3-5.6 \mathrm{M}$ & hollow fiber, PP & 0.6 & [145] \\
\hline Orange (clarified by MF) & $\mathrm{CaCl}_{2} 5.5 \mathrm{M}$ & hollow fiber, PP & 0.65 & [123] \\
\hline Orange, sucrose & $\mathrm{CaCl}_{2} \times 2 \mathrm{H}_{2} \mathrm{O} 4.9 \mathrm{M}$ & Hollow fiber, PP (Accurel ${ }^{\circledR}$ PP Q/32, Membrana GmbH, Wuppertal, Germany) & 0.9 (orange juice); 1.1 (sucrose) & [91] \\
\hline Kiwifruit (clarified by UF) & $\mathrm{CaCl}_{2} \times 2 \mathrm{H}_{2} \mathrm{O} 60 \% w / w$ & $\begin{array}{l}\text { hollow fiber, PP (Liqui-Cel }{ }^{\circledR} \text { Extra-Flow } 2.5 \times 8 \text {-in. membrane contactor, Hoechst-Celanese, } \\
\text { Wiesbaden, Germany) }\end{array}$ & 0.8 & [115] \\
\hline $\begin{array}{l}\text { Cactus pear (clarified by UF } \\
\text { preconcentrated by RO) }\end{array}$ & $\mathrm{CaCl}_{2} \times 2 \mathrm{H}_{2} \mathrm{O} 60 \% w / w$ & $\begin{array}{l}\text { hollow fiber, PP (Liqui-Cel }{ }^{\circledR} \text { Extra-Flow } 2.5 \times 8 \text {-in. membrane contactor, Hoechst-Celanese, } \\
\text { Wiesbaden, Germany) }\end{array}$ & 0.6 & [146] \\
\hline $\begin{array}{l}\text { Blackcurrant (clarified by MF and } \\
\text { preconcentrated by RO) }\end{array}$ & $\begin{array}{l}\mathrm{CaCl}_{2} \times 2 \mathrm{H}_{2} \mathrm{O}, 65^{\circ} \mathrm{Brix} \\
\text { (laboratory scale); } \mathrm{CaCl}_{2} \\
60.7^{\circ} \text { Brix (large scale) }\end{array}$ & $\begin{array}{l}\text { capillary, PP (MD } 020 \text { CP 2N, Microdyn-Nadir, Wiesbaden, Germany) (laboratory scale); } \\
\text { capillary, polypropylene (MD } 150 \text { CS 2N, Microdyn-Nadir, Wiesbaden, Germany) (large scale) }\end{array}$ & 0.7 (laboratory scale); 0.6 (large scale) & [40] \\
\hline $\begin{array}{l}\text { Pineapple (single strength and } \\
\text { clarified by MF) }\end{array}$ & $\mathrm{CaCl}_{2} 5.5-6 \mathrm{M}$ & $\begin{array}{l}\text { flat-sheet, thin PTFE layer sealed on a PP supporting net (TF200 Pall-Gelman, Washington, } \\
\text { NY, USA) }\end{array}$ & $\begin{array}{l}10.5 \text { (single strength juice); } \\
11 \text { (microfiltered juice) }\end{array}$ & [118] \\
\hline Noni (Morinda citrifolia) & $\mathrm{CaCl}_{2} 6 \mathrm{M}$ & hollow fiber, PP (Liqui Cel ${ }^{\circledR}$ minimodule $1.7 \times 5.5$ in., Wiesbaden, Germany) & 0.09 & [122] \\
\hline Apple (clarified by UF) & $\mathrm{CaCl}_{2} \times 2 \mathrm{H}_{2} \mathrm{O} 65 \% w / w$ & capillary, PP (MD 020 CP 2N, Microdyn-Nadir, Wiesbaden, Germany) & n.r. & [147] \\
\hline Roselle extract, apple and grape & $\mathrm{CaCl}_{2} 5.5-6 \mathrm{M}$ & hollow fiber, PP & $1.05-1.2$ & [121] \\
\hline Pomegranate (clarified by UF) & $\mathrm{CaCl}_{2} \times 2 \mathrm{H}_{2} \mathrm{O} 10.2 \mathrm{M}$ & $\begin{array}{l}\text { hollow fiber, PP (Liqui-Cel }{ }^{\circledR} \text { Extra-Flow } 2.5 \times 8 \text {-in. membrane contactor, Hoechst-Celanese, } \\
\text { Wiesbaden, Germany) }\end{array}$ & 0.5 & [126] \\
\hline $\begin{array}{l}\text { Apple (clarified by UF and } \\
\text { preconcentrated by RO) }\end{array}$ & $\mathrm{CaCl}_{2} 5.5 \mathrm{M}$ & $\begin{array}{l}\text { flat-sheet, thin PTFE layer sealed on a PP supporting net (TF200 Pall-Gelman, Washington, } \\
\text { NY, USA) }\end{array}$ & 0.75 & [140] \\
\hline Bergamot (clarified by UF) & $\mathrm{CaCl}_{2} \times 2 \mathrm{H}_{2} \mathrm{O} 10.2 \mathrm{M}$ & $\begin{array}{l}\text { hollow fiber, PP (Liqui-Cel }{ }^{\circledR} \text { Extra-Flow } 2.5 \times 8 \text {-in. membrane contactor, Hoechst-Celanese, } \\
\text { Wiesbaden, Germany) }\end{array}$ & 0.9 & [125] \\
\hline Passion fruit (clarified by UF) & $\mathrm{CaCl}_{2} 45 \% w / v$ & capillary, PP (MD 020 CP 2N, Microdyn-Nadir, Wiesbaden, Germany) & 0.52 & [148] \\
\hline $\begin{array}{l}\text { Chalupa (Passiflora maliformis) } \\
\text { (clarified by UF) }\end{array}$ & $\mathrm{CaCl}_{2} 45 \% w / v$ & capillary, PP (MD 020 CP 2N, Microdyn-Nadir, Wiesbaden, Germany) & 0.65 & [149] \\
\hline
\end{tabular}


Table 5. Cont.

\begin{tabular}{|c|c|c|c|c|}
\hline Fruit Juice & Osmotic Agent & Membrane Type & Average Flux $\left(\mathrm{kg} / \mathrm{m}^{2} \mathrm{~h}\right)$ & Ref. \\
\hline Pomegranate (clarified by UF) & $\mathrm{CaCl}_{2} \times 2 \mathrm{H}_{2} \mathrm{O} 65 \% w / w$ & hollow fiber, PP (MD 020 CP 2N, Microdyn-Nadir, Wiesbaden, Germany) & 1.1 & [150] \\
\hline Sucrose, apple and orange & $\mathrm{CaCl}_{2} 5 \mathrm{M}$ & hollow fiber, $\mathrm{PP}$ (Liqui Cel ${ }^{\circledR}$ contactor module X-50, Membrana, Charlotte, NC, USA) & $\begin{array}{l}0.35 \text { (sucrose, feed temperature } 35^{\circ} \mathrm{C} \text { ); } \\
0.18 \text { (apple, feed temperature } 30^{\circ} \mathrm{C} \text { ); } \\
0.081 \text { (orange, feed temperature } 30^{\circ} \mathrm{C} \text { ) }\end{array}$ & [124] \\
\hline Pomegranate (clarified by UF) & $\mathrm{CaCl}_{2} 6 \mathrm{M}$ & hollow fiber, PP (Liqui Cel ${ }^{\circledR}$ minimodule $1.7 \times 5.5$ in., Membrana, Charlotte, NC, USA) & 0.62 & [127] \\
\hline $\begin{array}{l}\text { Pomegranate } \\
\text { (clarified by PP spun filter) }\end{array}$ & $\mathrm{CaCl}_{2} \times 2 \mathrm{H}_{2} \mathrm{O} 6 \mathrm{M}$ & flat-sheet, PTFE and PVDF (TS Filter, Hangzhou, China) & 0.7 (PVDF); 1.5 (PTFE) & [129] \\
\hline $\begin{array}{l}\text { Pomegranate (clarified by UF, } \\
\text { preconcentrated by RO) }\end{array}$ & $\mathrm{CaCl}_{2} \times 2 \mathrm{H}_{2} \mathrm{O} 65 \% w / w$ & capillary, PP (MD 020 CP 2N, Microdyn-Nadir, Wiesbaden, Germany) & 0.65 & [151] \\
\hline Pomegranate & $\mathrm{CaCl}_{2} \times 2 \mathrm{H}_{2} \mathrm{O}$ & flat-sheet, nanofibous PEBA & 0.5 & [132] \\
\hline Black mulberry & $\mathrm{CaCl}_{2} \times 2 \mathrm{H}_{2} \mathrm{O} 65 \% w / w$ & capillary, PP (MD 020 CP 2N, Microdyn-Nadir, Wiesbaden, Germany) & n.r. & [133] \\
\hline Cranberry & $\mathrm{CaCl}_{2} 30,40$ and $50 \% w / w$ & hollow fiber, $\mathrm{PP}\left(\right.$ Liqui Cel ${ }^{\circledR}$ minimodule $1.7 \times 5.5$ in., Membrana, Charlotte, NC, USA) & $0.25-1.21$ & [134] \\
\hline $\begin{array}{l}\text { Cactus pear (filtered through } \\
\text { a sieve }<1 \mathrm{~mm} \text { ) }\end{array}$ & $\mathrm{CaCl}_{2} 43 \% w / w$ & $\begin{array}{l}\text { Flat-sheet, PTFE, } 0.45 \mu \mathrm{m} \text { and } 0.20 \mu \mathrm{m} \text { (Sartorius Stedim, Germany); flat-sheet, } \\
\text { PP, } 0.10 \mu \mathrm{m} \text { (Celgard, USA) }\end{array}$ & $\begin{array}{l}3 \text { (PTFE } 0.45 \mu \mathrm{m}) ; 2 \text { (PTFE } 0.2 \mu \mathrm{m} \text { ); } \\
1 \text { (PP } 0.10 \mu \mathrm{m})\end{array}$ & [135] \\
\hline Red grape & $\mathrm{CaCl}_{2} 50 \% w / w$ & $\begin{array}{l}\text { PTFE, } 0.20 \mu \mathrm{m} \text { (PTFE 11807, Sartorius, Germany); PTFE, } 0.45 \mu \mathrm{m} \text { (PTFE 11806, Sartorius, } \\
\text { Germany); PTFE, } 1.20 \mu \mathrm{m} \text { (PTFE 11802, Sartorius, Germany) }\end{array}$ & 6 & [136] \\
\hline Orange & $\begin{array}{l}\text { potassium pyrophosphate } \\
\text { solution } 1291 \mathrm{~g} / \mathrm{L}\end{array}$ & capillary, PP (MD 020 CP 2N, Microdyn-Nadir, Wiesbaden, Germany) & 0.3 & [144] \\
\hline
\end{tabular}

Legend: PP, polypropylene; PTFE, polytetrafluoroethylene; PVDF, polyvinylidene fluoride; PEBA, polyether-block-amide; n.r. not reported. 


\subsection{Osmotic Membrane Distillation}

Evaporation fluxes in OD can be significantly improved through a combination of OD and MD processes: the resulting process named as osmotic membrane distillation (OMD) results more effective than MD and OD alone [152,153]. Onsekizoglu et al. [147] compared the performance of different processes such as $\mathrm{MD}, \mathrm{OD}, \mathrm{OMD}$ and thermal evaporation in the concentration of clarified apple juice. Phenolic compounds, organic acids and sugars resulted very stable against all concentration processes, including thermal evaporation. Thermally evaporated samples showed the most significant color loss in comparison with clarified juice; on the other hand, the colors of samples concentrated by membrane-based processes were almost completely preserved, indicating the absence of Maillard reactions, as confirmed by subsequent analysis of 5-hydroxymethylfurfural. The OMD operation reduced significantly trans-2-hexenal losses resulting as the most promising alternative to conventional thermal evaporation technique.

OMD was also used to concentrate red fruits juices such as chokeberry, redcurrant and cherry up to $62-65^{\circ}$ Brix after a preliminary clarification by UF [154]. Juices were concentrated by using a membrane module equipped with 34 PP tubular membranes (Microdyn-Nadir, Wiesbaden, Germany) with a total effective internal area of $51 \mathrm{~cm}^{2}$; calcium chloride dehydrate $6 \mathrm{M}$ was used as stripping solution while bulk temperatures of feed and osmotic sides were fixed at 35 and $22^{\circ} \mathrm{C}$, respectively. In these conditions, average evaporation fluxes for clarified chokeberry juice were of about $4 \mathrm{~kg} / \mathrm{m}^{2} \mathrm{~h}$. For all red fruit juices the TAA was very well preserved in spite of relatively long operation time due to the low active membrane surface available. According to the experimental results the UF-OMD sequence was suggested as an outstanding approach of treating fruit juices of prominent dietary value.

\section{Recovery of Aroma Compounds}

Today, there is an increasing demand for manufacturing of flavor and fragrance ingredients which are involved within the food, cosmetic and pharmaceutical industries [155]. Flavors and fragrances imply a wide range of chemical compounds, including several molecules such as short-chain n-alkanes and alkenes, alcohols, aldehydes, ketones, esters, lactones, thiols and among other organic acids. Specially, there is a particular interest towards terpenes, which are recognized as the most abundant category of chemicals in nature, being responsible for primary odours in plants (flowers) and several fruits [156]. Aroma compounds are employed with the manufacturing processes of several processed foods (e.g., beverages, candies, dairy products), feedstocks, personal care, perfumes, and household products $[157,158]$. However, to satisfy such a demand of aromas, industries are using aroma molecules manufactured via chemical synthesis, which are a result of multiple reaction steps, requiring costly chiral educts and catalysts. Importantly, based on increasing consumers" "chemophobia", there is a big demand in replacing such chemically synthetized aromas with natural aromas [159]. In this way, there are two possible ways to naturally produce the aromas: (i) biosynthetic production [160], and (ii) conventional extraction from natural sources [161].

The conventional extraction is recognized as the most recommended way since aromas are contained in several agro-food products, including vegetables, herbals, fruits, processed foods, and their by-products. In general, the extraction can imply either chemical or physical separation techniques considering distillation, supercritical fluid technique, adsorption, microwave-assisted process, solvent extraction and membrane processes (e.g., pervaporation).

Regardless of all these techniques, there is an important issue to be considered since most of the aromas present reactivity (e.g., radical or oxidative) and low stability (e.g., thermal degradation and hydrolysis) when using either aqueous or solvent phases [162,163], producing limited recovery efficiencies and yields. Therefore, the aroma recovery depends primarily on the stability of targeted molecules. PV is currently a promising tool for the recovery of aroma compounds from fruit juices since it does not use temperature or any additional phases to carry out the extraction. Moreover, the lack of chemical agents in the extraction process contributes positively to the preservation of the flavor and aroma compounds' functional properties, minimizing the risk of possible contamination. 
The potential of pervaporation for recovering aroma compounds has been clearly demonstrated in the literature by a considerable amount of experimental work on laboratory scale. Almost 70 different components have already been tested and selectively recovered with the aid of this membrane technique [164].

Bengtsson et al. [165] reported high extraction efficiencies of organic compounds, such as alcohols (49-76\%), trans-2-hexenal (63\%) and esters (85-100\%), from apple juice. The authors proposed the use of an organophilic polydimethylsiloxane (PDMS) membrane, which exhibited considerably high enrichment factors (from 44 up to 125) toward the organic molecules. Similarly, using similar PDMS membranes, Baudot and Marin [166] recovered specific ester like ethyl acetate, achiving $\beta$ values in the range of $230-280$.

Cassano et al. [167] extracted selectively aroma solutes from kiwifruit juice using a commercial Pervap 1060 membrane (based on PDMS polymer). Such membrane had a preferential selective property towards methyl butanoate $(\beta=120)$ and ethyl butanoate $(\beta=100)$. In addition, the commercial membrane also exhibited a good separation ( $\beta=20-50)$ for 1-hexen-1-ol, $(E)-2$-hexen-1-ol, and 1-hexanol. Lately, the extracted aromas were used to fulfil the organoleptic quality properties of a concentrated kiwifruit juice. However, the successful recovery was due to right integrated membrane process developed by the authors. Such a process comprised the implementation of a ultrafiltration step as a pre-clarification of the kiwi juice and subsequently a osmotic distillation stage for the concentration of kiwi juice.

Rafia et al. [168] evaluated the recovery of characteristic aromas of lemon juice from using a commercial hydrophobic poly(octylmethylsiloxane) (POMS) membrane. This organophilic membrane revealed selective properties for cyclic terpenes, such as $\alpha$-pinene, $\beta$-pinene and limonene. Interestingly, an increase in feed temperature promoted the increase of water permeation rate more significantly than the aroma recovery rate, which resulted in a reduction of the recovery efficiency. According to the applied operating temperature (between $25-60^{\circ} \mathrm{C}$ ), the activation energy for the aroma compounds is lower than water. This analysis indicated that the permeation of aromas across POMS membrane was less temperature dependent compared to water. In this context, it is likely that the commercial membrane is suggested for the separation of these specific molecules (i.e., $\alpha$-pinene, $\beta$-pinene and limonene) since lower temperatures minimize the thermal degradation of thermolabile substances.

Raisi and Aroujalian [169] separated organic aromas such as 3-methyl butanal, isopentyl butanal, n-hexanol, isopentyl acetate, $\alpha$-Ionone from pomegranate juice by using composite membranes. Especially, membranes based on PDMS-PVDF-PP and POMS-PVDF-PP selective composite layers were applied. The composites demonstrated total permeate fluxes between $0.300-0.350 \mathrm{~kg} / \mathrm{m}^{2} \mathrm{~h}$. While the most highly selective membrane was the POMS-based composite membrane, showing higher affinity ( $\beta=55$ ) towards isopentyl butanal than the composite based on PDMS $(\beta=20)$.

One of the main sources of aroma compounds is definitely the coffee, which has been a target of aromas extraction for their possible use in beverages. Coffee is likely the most known for its characteristic scent notes associated to several molecules, including 2-methylbutanoic acid, 2-methylpropanal, hexanal and (E)-2-nonenal. To the date, more than 65 different types of odorant molecules have been identified in coffee [170]. Towards the extraction of its aromas, Weschenfelder et al. [171] recovered and concentrated 2,3-butanedione and 2-5-dimethyl pyrazine molecules from an industrial coffee solution. These compounds are recognized for their basic scent notes, e.g., creamy, buttery, sweet, milky and nutty-like smells. The molecules were extracted using commercially available organophilic PDMS-based Pervatech BV membrane which exhibited high selective properties towards 2-5-dimethyl pyrazine and 2,3-butanedione, providing a $\beta$ value between $42-45$. The membranes also exhibited relatively high organic permeate fluxes of $\sim 0.432 \mathrm{~kg} / \mathrm{m}^{2} \mathrm{~h}$. Comparing to other membrane-based technologies, it is likely PV finds its main drawback in the low permeate rates. Nevertheless, a rise in operating temperature tends to provoke an increase permeation flux in polymer membranes according to the free volume theory [22], but a negative impact on the membrane separation efficiency could be expected. It has been documented that operating temperature increase results in higher polymeric chain motions, promoting an easier transport of larger molecules and consequently decrease the selective membrane 
properties [26]. This is because the free volume increase facilitates the diffusion transport of larger molecules resulting in a loss in selectivity [22,172].

Finally, a current trend in aroma recovery also deals with the use of derivatives from fruit processing industries as a new feedstock, in which the recovered aromas could be re-used in the preparation of new foods and formulations. Bergamot peel oils have been examined as a feedstock for aroma recovery. Figoli et al. [173] developed an enzyme-assisted process for the extraction of typical aroma molecules of citric natural products, such as linalool, bergapten, linalyl acetate, and most relevantly, limonene; a cyclic terpene which gives the main characteristic essence of bergamot fruits. The authors also stated the successful extraction of linalool and linalyl acetate using PDMS-based polymer membranes from bergamot by-product [174], in which the membranes displayed $\beta$ value enhancements with increasing temperature.

In a different approach, the concentration of natural aroma compounds (mainly pentan-1-ol, hexanal, butyl acetate, heptan-1-ol) from different fruit juice hydrolates (such as plum, apple, blackcurrant and cherry) has been proposed [175]. By performing the optimization, aromas in the permeates concentrated approximately 11, 9, 57 times compared to their concentration in the feed solution for apple, cherry and blackcurrant hydrolate, respectively. Very recently, Galiano et al. [176] performed the extraction of limonene, linalool and linalyl acetate from the same bergamot by-product, however, for a better extraction, the product was preliminary assisted by enzymatic treatment. Experimentally, at $25^{\circ} \mathrm{C}$, both commercial membranes, like POMS-PEI and PDMS-1070, showed no significant differences in terms of $\beta$ values independently from the pre-treatment. However, the separation efficiency was higher when enzymes were used (at $\left.40^{\circ} \mathrm{C}\right)$.

Recently, Podstawczyk et al. [177] presented an economic analysis of the production of concentrated apple juice hydrolates through PV membranes. The investment costs for a continuous process (feed flowrate of raw material of $1000 \mathrm{~kg} / \mathrm{h}$ ) resulted significantly smaller ( $€ 285370.5)$ than operating costs ( $€ 712$ 120.94). The unitary cost of the final product was estimated to be $9.43 € / \mathrm{kg}$; therefore, a product price of $15.00 € / \mathrm{kg}$ gave a margin of $37 \%$. According to the economic analysis results, PV is a profitable and feasible option for aroma recovery from fruit hydrolates. Typical aroma compounds recovered by PV from fruit juices are summarized in Table 6. 
Table 6. Recovery of aromas and fruit juice processing via PV technology.

\begin{tabular}{|c|c|c|c|c|c|c|}
\hline Aromas & Original Source & Membrane Material & $\begin{array}{l}\text { Operating } \\
\text { Conditions }\end{array}$ & $\begin{array}{c}\text { Permeate Flux } \\
\left(\mathrm{kg} / \mathrm{m}^{2} \mathrm{~h}\right)\end{array}$ & $\begin{array}{c}\text { Enrichment Factor } \\
(\beta)\end{array}$ & Reference \\
\hline $\begin{array}{l}\text { Ethyl acetate } \\
\text { Ethyl butanoate } \\
\text { Ethyl hexanoate }\end{array}$ & Tropical fruit juice & $\begin{array}{l}\text { Commercial Pervap 1070, } \\
\text { hydrophobic }\end{array}$ & $25^{\circ} \mathrm{C}, 3.9 \mathrm{mbar}$ & $\begin{array}{l}0.077 \\
0.077 \\
0.055\end{array}$ & $\begin{array}{l}124 \\
410 \\
213\end{array}$ & [178] \\
\hline $\begin{array}{l}\text { Methyl butyrate } \\
\text { Ethyl butyrate }\end{array}$ & Strawberry & $\begin{array}{l}\text { Commercial Pervap 1070, } \\
\text { hydrophobic }\end{array}$ & $50^{\circ} \mathrm{C}, 4 \mathrm{mbar}$ & $\begin{array}{l}0.25 \\
0.15\end{array}$ & $\begin{array}{l}90 \\
55\end{array}$ & [179] \\
\hline $\begin{array}{l}\text { Methyl butanoate } \\
\text { 1-hexen-1-ol } \\
\text { (E)-2-hexen-1-ol }\end{array}$ & $\begin{array}{l}\text { Clarified kiwifruit } \\
\text { juice }\end{array}$ & $\begin{array}{l}\text { Commercial Pervap 1060, } \\
\text { hydrophobic }\end{array}$ & $20^{\circ} \mathrm{C}, 5 \mathrm{mbar}$ & 0.13 & $\begin{array}{l}120 \\
20 \\
20\end{array}$ & [167] \\
\hline $\begin{array}{l}\text { (E)-2-hexenal } \\
\text { (E)-2-hexen-1-ol } \\
\text { 1-octen-2-ol } \\
\text { 1-hexanol }\end{array}$ & Kiwifruit juice & $\begin{array}{l}\text { SBS composite, } \\
\text { hydrophobic }\end{array}$ & $20^{\circ} \mathrm{C}, 5 \mathrm{mbar}$ & 0.001 & $\begin{array}{l}70 \\
55 \\
32 \\
80\end{array}$ & [180] \\
\hline $\begin{array}{l}\text { Ethyl acetate } \\
\text { Ethyl butyrate } \\
\text { Hexanal } \\
\text { Limonene }\end{array}$ & Orange juice & PDMS, hydrophobic & $50^{\circ} \mathrm{C}, 1 \mathrm{mbar}$ & $\begin{array}{l}0.0001 \\
0.0001 \\
0.0001 \\
0.0035\end{array}$ & $\begin{array}{l}11 \\
6 \\
6 \\
12\end{array}$ & [181] \\
\hline $\begin{array}{l}\text { Linalool } \\
\text { Linalyl acetate }\end{array}$ & Bergamot essential oil & $\begin{array}{l}\text { Commercial Pervap 1070, } \\
\text { hydrophobic }\end{array}$ & $40^{\circ} \mathrm{C}, 1 \mathrm{mbar}$ & $\begin{array}{l}0.20 \\
0.25\end{array}$ & $\begin{array}{l}28 \\
55\end{array}$ & [174] \\
\hline $\begin{array}{l}\text { 3-methyl butanal } \\
\text { Isopentyl acetate } \\
\text { n-Hexanol } \\
\alpha \text {-Ionone }\end{array}$ & Pomegranate juice & PDMS, hydrophobic & $30^{\circ} \mathrm{C}, 0 \mathrm{mbar}$ & $\begin{array}{l}0.140 \\
0.200 \\
0.050 \\
0.040\end{array}$ & $\begin{array}{l}23 \\
21 \\
19 \\
9\end{array}$ & [182] \\
\hline $\begin{array}{l}\text { 3-methyl butanal } \\
\text { Isopentyl acetate } \\
\text { n-Hexanol } \\
\alpha \text {-Ionone } \\
\text { Isobutanol } \\
\text { Isoamyl alcohol } \\
\text { Ethyl acetate }\end{array}$ & Pomegranate juice & PDMS, hydrophobic & $30^{\circ} \mathrm{C}, 0 \mathrm{mbar}$ & $\begin{array}{l}0.0005 \\
0.0005 \\
0.0004 \\
0.0002\end{array}$ & $\begin{array}{l}15 \\
16 \\
15 \\
6 \\
2.5 \\
3.0 \\
8.2\end{array}$ & [169] \\
\hline
\end{tabular}


Table 6. Cont

\begin{tabular}{|c|c|c|c|c|c|c|}
\hline Aromas & Original Source & Membrane Material & $\begin{array}{l}\text { Operating } \\
\text { Conditions }\end{array}$ & $\begin{array}{l}\text { Permeate Flux } \\
\left(\mathrm{kg} / \mathrm{m}^{2} \mathrm{~h}\right)\end{array}$ & $\begin{array}{c}\text { Enrichment Factor } \\
(\beta)\end{array}$ & Reference \\
\hline $\begin{array}{l}\alpha \text {-Pinene } \\
\beta \text {-Pinene } \\
\text { Limonene }\end{array}$ & Lemon Juice & $\begin{array}{l}\text { POMS, } \\
\text { hydrophobic/organophilic }\end{array}$ & $30^{\circ} \mathrm{C}, 0 \mathrm{mbar}$ & $\begin{array}{l}0.0004 \\
0.0003 \\
0.0009\end{array}$ & $\begin{array}{l}22 \\
18 \\
16\end{array}$ & [168] \\
\hline $\begin{array}{l}\text { Isoamyl alcohol } \\
\text { Methyl 2-methylbutanoate } \\
\text { Methyl hexanoate }\end{array}$ & Pineapple juice & $\begin{array}{l}\text { Commercial PDMS } \\
\text { Pervatech BV, hydrophobic }\end{array}$ & $50^{\circ} \mathrm{C}$, sweeping-gas & $\begin{array}{l}0.0002 \\
0.002 \\
0.0002\end{array}$ & $\begin{array}{l}75 \\
80 \\
25\end{array}$ & [183] \\
\hline $\begin{array}{l}\text { 2,3-butanedione } \\
\text { 2,3-pentanedione } \\
\text { 3-methylbutanal } \\
\text { Benzaldehyde } \\
\text { Acetaldehyde }\end{array}$ & Soluble coffee extract & $\begin{array}{l}\text { Commercial PDMS } \\
\text { Pervatech BV, } \\
\text { hydrophobic/organophilic }\end{array}$ & $20^{\circ} \mathrm{C}, 2.5 \mathrm{mbar}$ & 0.432 & $\begin{array}{l}45 \\
7 \\
8 \\
4 \\
5\end{array}$ & {$[171]$} \\
\hline $\begin{array}{l}\text { Benzaldehyde } \\
\text { 1-hexanol isoamylalcohol } \\
\text { hexanal benzylalcohol } \\
\text { 2-phenylethanol }\end{array}$ & Grape must & $\begin{array}{l}\text { Commercial PDMS } \\
\text { Pervatech BV, } \\
\text { hydrophobic/organophilic }\end{array}$ & $16^{\circ} \mathrm{C}, 60 \mathrm{mbar}$ & 0.100 & $1-2$ & [184] \\
\hline $\begin{array}{l}\text { Pentan-1-ol, } \\
\text { Hexanal } \\
\text { Butyl acetate } \\
\text { Heptan-1-ol }\end{array}$ & $\begin{array}{l}\text { Plum, apple, } \\
\text { blackcurrant and } \\
\text { cherry hydrolysates }\end{array}$ & $\begin{array}{l}\text { Commercial Pervap ECO } \\
\text { 001BP, hydrophobic }\end{array}$ & $60^{\circ} \mathrm{C}, 3000 \mathrm{mbar}$ & 0.008 & $\begin{array}{l}5800 \\
3678 \\
8602 \\
1131\end{array}$ & {$[175]$} \\
\hline Linalyl acetate & Bergamot peel oil & PDMS-1070, hydrophobic & $40^{\circ} \mathrm{C}, 3 \mathrm{mbar}$ & 1.100 & 45 & [176] \\
\hline
\end{tabular}




\section{Conclusions}

Membrane-based operations have proven to be attractive alternatives to the conventional clarification and concentration methodologies of fruit juices from both economic and qualitative point of view. In particular, MF and UF operations allow to substitute the fining step of the traditional step with significant advantages in terms of low energy requirements and costs, reduction of thermal damage, simpler process design, reduction of waste products and enzymes, increased juice yield, easy cleaning and maintenance of the equipment. $\mathrm{RO}, \mathrm{MD}$ and $\mathrm{OD}$ represent useful alternatives to the use of thermal evaporation in fruit juice concentration. By applying $\mathrm{RO}$ concentration levels of $20-25^{\circ} \mathrm{Brix}$ can be achieved with energy saving of 60-75\% compared to direct evaporation. Highest concentration levels (up to $65-70{ }^{\circ}$ Brix) can be achieved by MD and OD operating at low temperature and pressure, thereby maintaining original organoleptic and sensorial characteristics of the fresh juice. Finally, the pervaporative recovery or concentration of aroma compounds from fruit juices is a promising alternative to the conventional use of distillation, partial condensation and their combination.

Well-developed process engineering, including pre-treatment, selection of appropriate membrane modules and membrane materials, optimization of operating and fluid-dynamic conditions appear as key factors to overcome intrinsic limitations related to fouling and short lifespan of the membranes. Further developments are expected in this area through the combination of conventional processes with membrane technology as well as the development of integrated membrane systems as clearly demonstrated by several applications on laboratory and semi-industrial scale.

Author Contributions: Conceptualization, A.C., C.C. and R.C.-M.; investigation, A.C., C.C. and R.C.-M.; writing-original draft preparation, A.C., C.C. and R.C.-M.; writing-review and editing, A.C.; visualization, A.C., C.C. and R.C.-M.; supervision, A.C. All authors have read and agreed to the published version of the manuscript.

Funding: This research received no external funding.

Conflicts of Interest: The authors declare no conflict of interest.

\section{References}

1. Fruit \& Vegetable Processing Market by Product Type, Equipment, Operation, and Region-Global Forecast to 2022. Available online: https://www.marketsandmarkets.com/Market-Reports/fruit-vegetable-processingmarket-140232885.html (accessed on 3 February 2020).

2. Lazarides, H.N. Food processing technology in a sustainable food supply chain. Procedia Food Sci. 2011, 1, 1918-1923. [CrossRef]

3. Jing, L.; Howard, A.C. Applications of membrane techniques for purification of natural products. Biotechnol. Lett. 2010, 32, 601-608.

4. Echavarria, A.P.; Torras, C.; Pagan, J.; Ibarz, A. Fruit juice processing and membrane technology application. Food Eng. Rev. 2011, 3, 136-158. [CrossRef]

5. Samborska, K.; Kamińska, P.; Jedlińska, A.; Matwijczuk, A.; Kamińska-Dwórznicka, A. Membrane processing in the sustainable production of low-sugar apple-cranberry cloudy juice. Appl. Sci. 2018, 8, 1082. [CrossRef]

6. Global Membrane Technology Market for Food and Beverage Processing (2019-2024). Available online: https://www.autumnmarketresearch.com/industry-reports/global-membrane-technology-market-forfood-and-beverage-processing-2019-2024/ (accessed on 3 February 2020).

7. Strathmann, H.; Giorno, L.; Drioli, E. An Introduction to Membrane Science and Technology; Consiglio Nazionale delle Ricerche: Rome, Italy, 2006.

8. Childress, A.E.; Elimelech, M. Relating nanofiltration membrane performance to membrane charge (electrokinetic) characteristics. Environ. Sci. Technol. 2000, 34, 3710-3716. [CrossRef]

9. Ripperger, S.; Almann, J. Crossflow microfiltration-state of the art. Sep. Purif. Technol. 2002, 26, 19-31. [CrossRef]

10. Ramadan, A.; Gyula, V.; Bekassy-Molnar, E.; Balint, A. Investigation of ultra- and nanofiltration for utilization of whey protein and lactose. J. Food Process Eng. 2005, 67, 325-332.

11. Fievet, P.; Labbez, C.; Szymczyk, A.; Vidonne, A.; Foissy, A.; Pagetti, J. Electrolyte transport through amphoteric nanofiltration membranes. Chem. Eng. Sci. 2002, 57, 2921-2931. [CrossRef] 
12. Mulder, M. Basic Principles of Membrane Technology, 2nd ed.; Kluwer Academic Publishers: Dordrecht, The Netherlands, 1996; pp. 280-306.

13. Cheryan, M. Ultrafiltration and Microfiltration Handbook; Technomic Publishing Company: Lancaster, PA, USA, 1998.

14. Kostantinos, B.P.; Harris, N.L. Osmotic concentration of liquid foods. J. Food Eng. 2001, 49, 201-206.

15. Jiao, B.; Cassano, A.; Drioli, E. Recent advances on membrane processes for the concentration of fruit juices: A review. J. Food Eng. 2004, 63, 303-324. [CrossRef]

16. Susanto, H. Towards practical implementations of membrane distillation. Chem. Eng. Process. 2011, 50, 139-150. [CrossRef]

17. Hogan, P.A.; Canning, R.P.; Peterson, P.A.; Johnson, R.A.; Michaels, A.S. A new option: Osmotic distillation. Chem. Eng. Prog. 1998, 94, 49-61.

18. Peñaranda-López, A.L.; Martínez-Alvarado, J.C.; Muvdi-Nova, C.J.; Torrestiana-Sánchez, B. Development and validation of a theoretical model for osmotic evaporation. Desalination 2016, 384, 52-59. [CrossRef]

19. Wang, P.; Chung, T.S. Recent advances in membrane distillation processes: Membrane development, configuration design and application exploring. J. Membr. Sci. 2015, 474, 39-56. [CrossRef]

20. Gryta, M. Concentration of $\mathrm{NaCl}$ solution by membrane distillation integrated with crystallization. Sep. Sci. Technol. 2002, 37, 3535-3558. [CrossRef]

21. Bandini, S.; Gostoli, C.; Sarti, G.C. Separation efficiency in vacuum membrane distillation. J. Membr. Sci. 1992, 73, 39-52. [CrossRef]

22. Wijmans, J.G.; Baker, R.W. The solution-diffusion model: A review. J. Membr. Sci. 1995, 107, 1-21. [CrossRef]

23. Crespo, J.; Brazinha, C. Fundamentals of pervaporation. In Pervaporation, Vapour Permeation and Membrane Distillation; Basile, A., Figoli, A., Khayet, M., Eds.; Elsevier Ltd.: Cambridge, UK, 2015; pp. 1-17.

24. Castro-Muñoz, R. Pervaporation: The emerging technique for extracting aroma compounds from food systems. J. Food Eng. 2019, 253, 27-39. [CrossRef]

25. Kujawski, W.; Krajewski, S.R. Sweeping gas pervaporation with hollow-fiber ion-exchange membranes. Desalination 2004, 162, 129-135. [CrossRef]

26. Baker, R.W.; Wijmans, J.G.; Huang, Y. Permeability, permeance and selectivity: A preferred way of reporting pervaporation performance data. J. Membr. Sci. 2010, 348, 346-352. [CrossRef]

27. Sandri, I.G.; Fontana, R.C.; Barfknecht, D.M.; da Silveira, M.M. Clarification of fruit juices by fungal pectinases. LWT Food Sci. Technol. 2011, 44, 2217-2222. [CrossRef]

28. Stounbjerg, L.; Vestergaard, C.; Andreasen, B.; Ipsen, R. Beverage clouding agents: Review of principles and current manufacturing. Food Rev. Int. 2018, 34, 613-638. [CrossRef]

29. Vaillant, F.; Milling, P.; O’Brien, G.; Dornier, M.; Reynes, M. Crossflow microfiltration of passion fruit juice after partial enzymatic liquefaction. J. Food Eng. 1999, 48, 83-90. [CrossRef]

30. Qaid, S.; Zait, M.; El Kacemi, K.; El Midaoui, A.; El Hajjil, H.; Taky, M. Ultrafiltration for clarification of Valencia orange juice: Comparison of two flat sheet membranes on quality of juice production. J. Mater. Environ. Sci. 2017, 8, 1186-1194.

31. Chung, T.S.; Qin, J.J.; Gu, J. Effect of shear rate within the spinneret on morphology, separation performance and mechanical properties of ultrafiltration polyethersulfone hollow fiber membranes. Chem. Eng. Sci. 2000, 55, 1077-1091. [CrossRef]

32. Urošević, T.; Povrenović, D.; Vukosavljević, P.; Urošević, I.; Stevanović, S. Recent developments in microfiltration and ultrafiltration of fruit juices. Food Bioprod. Process. 2017, 106, 147-161. [CrossRef]

33. Cassano, A.; Donato, L.; Drioli, E. Ultrafiltration of kiwifruit juice: Operating parameters, juice quality and membrane fouling. J. Food Eng. 2007, 79, 613-621. [CrossRef]

34. Cassano, A.; Donato, L.; Conidi, C.; Drioli, E. Recovery of bioactive compounds in kiwifruit juice by ultrafiltration. Innov. Food Sci. Emerg. Technol. 2008, 9, 556-562. [CrossRef]

35. Laorko, A.; Zhenyu, L.; Tongchitpakdee, S.; Chantachum, S.; Youravong, W. Effect of membrane property and operating conditions on phytochemical properties and permeate flux during clarification of pineapple juice. J. Food Eng. 2010, 100, 514-521. [CrossRef]

36. Sagu, S.T.; Karmakar, S.; Nso, E.J.; Kapseu, C.; De, S. Ultrafiltration of banana (Musa acuminata) juice using hollow fibers for enhanced shelf life. Food Bioprocess Technol. 2014, 7, 2711-2722. [CrossRef]

37. Galiano, F.; Figoli, A.; Conidi, C.; Menichini, F.; Bonesi, M.; Loizzo, M.R.; Cassano, A.; Tundis, R. Functional properties of Punica granatum L. juice clarified by hollow fiber membranes. Processes 2016, 4, 21. [CrossRef] 
38. De Bruijn, J.P.F.; Venegas, A.; Martinez, J.A.; Borquez, R. Ultrafiltration performance of Carbosep membranes for the clarification of apple juice. LWT Food Sci. Technol. 2003, 36, 397-406. [CrossRef]

39. Verma, S.P.; Sarkar, B. Analysis of flux decline during ultrafiltration of apple juice in a batch cell. Food Bioprod. Proc. 2015, 94, 147-157. [CrossRef]

40. Kozák, Á.; Bánvölgyi, S.; Vincze, I.; Kiss, I.; Békássy Molnár, E.; Vatai, G. Comparison of integrated large-scale and laboratory scale membrane processes for the production of black currant juice concentrate. Chem. Eng. Process. 2008, 47, 1171-1177. [CrossRef]

41. Conidi, C.; Cassano, A.; Drioli, E. A membrane-based study for the recovery of polyphenols from bergamot juice. J. Membr. Sci. 2011, 375, 182-190. [CrossRef]

42. Conidi, C.; Destani, F.; Cassano, A. Performance of hollow fiber ultrafiltration membranes in the clarification of blood orange juice. Beverages 2015, 1, 341-353. [CrossRef]

43. Toker, R.; Karhan, M.; Tetik, N.; Turhan, I.; Oziyci, H.R. Effect of ultrafiltration and concentration processes on the physical and chemical composition of blood orange juice. J. Food Process Preserv. 2014, 38, 1321-1329. [CrossRef]

44. Cassano, A.; Conidi, C.; Drioli, E. Physico-chemical parameters of cactus pear (Opuntia ficus-indica) juice clarified by microfiltration and ultrafiltration processes. Desalination 2010, 250, 1101-1104. [CrossRef]

45. Ennouri, M.; Ben Hassan, I.; Ben Hassen, H.; Lafforgue, C.; Schmitz, P.; Ayadi, A. Clarification of purple carrot juice: Analysis of the fouling mechanisms and evaluation of the juice quality. J. Food Sci. Technol. 2015, 52, 2806-2814. [CrossRef]

46. Qin, G.; Lü, X.; Wei, W.; Li, J.; Cui, R.; Hu, S. Microfiltration of kiwifruit juice and fouling mechanism using fly-ash-based ceramic membranes. Food Bioprod. Process. 2015, 96, 278-284. [CrossRef]

47. Dahdouh, L.; Wisniewski, C.; Ricci, J.; Kapitan-Gnimdu, A.; Dornier, M.; Delalonde, M. Development of an original lab-scale filtration strategy for the prediction of microfiltration performance: Application to orange juice clarification. Sep. Purif. Technol. 2015, 56, 42-50. [CrossRef]

48. Cassano, A.; Marchio, M.; Drioli, E. Clarification of blood orange juice by ultrafiltration: Analyses of operating parameters, membrane fouling and juice quality. Desalination 2007, 212, 15-27. [CrossRef]

49. Nourbakhsh, H.; Emam-Djomeh, Z.; Mirsaeedghazi, H.; Omid, M.; Moieni, S. Study of different fouling mechanisms during membrane clarification of red plum juice. Int. J. Food Sci. Technol. 2014, 49, 58-64. [CrossRef]

50. Mirsaeedghazi, H.; Emam-Djomeh, Z. Clarification of bitter orange (Citrus aurantium) juice using microfiltration with mixed cellulose esters membrane. J Food Process Preserv. 2017, 41, e12738. [CrossRef]

51. Espamer, L.; Pagliero, C.; Ochoa, A.; Marchese, J. Clarification of lemon juice using membrane process. Desalination 2006, 200, 565-567. [CrossRef]

52. Oliveira, R.C.; Docê, R.C.; Barros, S.T.D. Clarification of passion fruit juice by microfiltration: Analyses of operating parameters, study of membrane fouling and juice quality. J. Food Eng. 2012, 111, 432-439. [CrossRef]

53. Domingues, R.C.C.; Ramos, A.A.; Cardoso, V.L.; Reis, M.H.M. Microfiltration of passion fruit juice using hollow fibre membranes and evaluation of fouling mechanisms. J. Food Eng. 2014, 121, 73-79. [CrossRef]

54. Laorko, A.; Tongchitpakdee, S.; Youravong, W. Storage quality of pineapple juice non-thermally pasteurized and clarified by microfiltration. J. Food Eng. 2013, 116, 554-561. [CrossRef]

55. De Barros, S.T.D.; Andrade, C.M.G.; Mendes, E.S.; Peres, L. Study of fouling mechanism in pineapple juice clarification by ultrafiltration. J. Membr. Sci. 2003, 215, 213-224. [CrossRef]

56. Mirsaeedghazi, H.; Emam-Djomeh, Z.; Mousavi, S.M.; Aroujalian, A.; Navidbakhsh, M. Clarification of pomegranate juice by microfiltration with PVDF membranes. Desalination 2010, 264, 243-248. [CrossRef]

57. Conidi, C.; Cassano, A.; Caiazzo, F.; Drioli, E. Separation and purification of phenolic compounds from pomegranate juice by ultrafiltration and nanofiltration membranes. J. Food Eng. 2017, 195, 1-13. [CrossRef]

58. Aghdam, M.A.; Mirsaeedghazi, H.; Aboonajmi, M.; Kianmehr, M.H. The effect of ultrasound waves on the efficiency of membrane clarification of pomegranate juice. Int. J. Food Sci. Technol. 2015, 50, 892-898. [CrossRef]

59. Mirsaeedghazi, H.; Mousavi, S.M.; Emam-Djomeh, Z.; Rezaei, K.; Aroujalian, A.; Navidbakhsh, M. Comparison between ultrafiltration and microfiltration in the clarification of pomegranate juice. J. Food Process Eng. 2012, 35, 424-436. [CrossRef]

60. Bagci, P.O. Effective clarification of pomegranate juice: A comparative study of pretreatment methods and their influence on ultrafiltration flux. J. Food Eng. 2014, 141, 58-64. [CrossRef] 
61. Rai,C.; Rai, P.; Majumdar, G.C.; De, S.; DasGupta, S. Mechanism of permeate flux decline during microfiltration of watermelon (Citrullus lanatus) juice. Food Bioprocess Technol. 2010, 3, 545-553. [CrossRef]

62. Vladisavljević, G.T.; Vukosavljević, P.; Bukvić, M.S. Permeate flux and fouling resistance in ultrafiltration of depectinized apple juice using ceramic membranes. J. Food Eng. 2003, 60, 241-247. [CrossRef]

63. Gulec, H.A.; Bagci, P.O.; Bagci, U. Performance enhancement of ultrafiltration in apple juice clarification via low-pressure oxygen plasma: A comparative evaluation versus pre-flocculation treatment. LWT Food Sci. Technol. 2018, 91, 511-517. [CrossRef]

64. Gulec, H.A.; Bagci, P.O.; Bagci, U. Clarification of apple juice using polymeric ultrafiltration membranes: A comparative evaluation of membrane fouling and juice quality. Food Bioprocess Technol. 2017, 10, 875-885. [CrossRef]

65. Vladisavljević, G.T.; Vukosavljević, P.; Veljović, M.S. Clarification of red raspberry juice using microfiltration with gas backwashing: A viable strategy to maximize permeate flux and minimize a loss of anthocyanins. Food Bioprod. Process. 2013, 91, 473-480. [CrossRef]

66. Yazdanshenas, M.; Tabatabaee-Nezhad, S.A.R.; Soltanieh, M.; Roostaazad, R.; Khoshfetrat, A.B. Contribution of fouling and gel polarization during ultrafiltration of raw apple juice at industrial scale. Desalination 2010, 258, 194-200. [CrossRef]

67. Hojjatpanah, G.; Emam-Djomeh, Z.; Kalbasi Ashtari, A.; Mirsaeedghazi, H.; Omid, M. Evaluation of the fouling phenomenon in the membrane clarification of black mulberry juice. Int. J. Food Sci. Technol. 2011, 46, 1538-1544. [CrossRef]

68. Jaffrin, M.Y. Dynamic shear-enhanced membrane filtration: A review of rotating disks, rotating membranes and vibrating systems. J. Membr. Sci. 2008, 324, 7-25. [CrossRef]

69. Luo, J.; Zhu, Z.; Ding, L.; Bals, O.; Wan, Y.; Jaffrin, M.Y.; Vorobiev, E. Flux behavior in clarification of chicory juice by high-shear membrane filtration: Evidence for threshold flux. J. Membr. Sci. 2013, 435, 120-129. [CrossRef]

70. Bacchin, P.; Aimar, P.; Field, R.W. Critical and sustainable fluxes: Theory, experiments and applications. J. Membr. Sci. 2006, 281, 42-69. [CrossRef]

71. Field, R.W.; Pearce, G.K. Critical, sustainable and threshold fluxes for membrane filtration with water industry applications. Adv. Colloid Interface Sci. 2011, 164, 38-44. [CrossRef] [PubMed]

72. Lutz, H. Ultrafiltration: Fundamentals and Engineering. In Comprehensive Membrane Science and Engineering; Drioli, E., Giorno, L., Eds.; Elsevier, B.V.: Kidlington, UK, 2010; Volume 2, pp. 115-139.

73. Cassano, A.; Conidi, C.; Tasselli, F. Clarification of pomegranate juice (Punica granatum L.) by hollow fibre membranes: Analyses of membrane fouling and performance. J. Chem. Technol. Biotechnol. 2015, 90, 859-866. [CrossRef]

74. Laorko, A.; Li, Z.; Tongchitpakdee, S.; Youravong, W. Effect of gas sparging on flux enhancement and phytochemical properties of clarified pineapple juice by microfiltration. Sep. Purif. Technol. 2011, 80, 445-451. [CrossRef]

75. Hérmia, J. Constant pressure blocking filtration laws. Applications to power-law non Newtonian fluids. Trans. IChemE 1982, 60, 183-187.

76. Field, R.W.; Wu, D.; Howell, J.A.; Gupta, B.B. Critical flux concept for microfiltration fouling. J. Membr. Sci. 1995, 100, 259-272. [CrossRef]

77. Mirsaeedghazi, H.; Emam-Djomeh, Z.; Mousavi, S.M.; Aroujalian, A.; Navidbakhsh, M. Changes in blocking mechanisms during membrane processing of pomegranate juice. Int. J. Food Sci. Technol. 2009, 44, 2135-2141. [CrossRef]

78. Razi, B.; Aroujalian, A.; Fathizadeh, M. Modeling of fouling layer deposition in cross-flow microfiltration during tomato juice clarification. Food Bioprod. Process. 2012, 90, 841-848. [CrossRef]

79. Jiraratananon, R.; Chanachai, A. A study of fouling in the ultrafiltration of passion fruit juice. J. Membr. Sci. 1996, 111, 39-48. [CrossRef]

80. De Bruijn, J.; Venegas, A.; Borquez, R. Influence of crossflow ultrafiltration on membrane fouling and apple juice quality. Desalination 2002, 148, 131-136. [CrossRef]

81. Tasselli, F.; Cassano, A.; Drioli, E. Ultrafiltration of kiwifruit juice using modified poly (ether ether ketone) hollow fibre membranes. Sep. Pur. Technol. 2007, 57, 94-102. [CrossRef] 
82. Nourbakhsh, H.; Alemi, A.; Emam-Djomeh, Z.; Mirsaeedghazi, H. Effect of processing parameters on fouling resistances during microfiltration of red plum and watermelon juices: A comparative study. J. Food Sci. Technol. 2014, 49, 58-64. [CrossRef]

83. Sharifanfar, R.; Mirsaeedghazi, H.; Fadavi, A.; Kianmehr, M.H. Effect of feed canal height on the efficiency of membrane clarification of pomegranate juice. J Food Process Preserv. 2015, 39, 881-886. [CrossRef]

84. Vaillant, F.; Millan, A.; Dornier, M.; Decloux, M.; Reynes, M. Strategy for economical optimisation of the clarifcation of pulpy fruit juices using crossflow microfiltration. J. Food Eng. 2001, 48, 83-90. [CrossRef]

85. Rai, P.; Majumdar, G.C.; Das Gupta, S.; De, S. Effect of various pretreament methods on permeate flux and quality during ultrafiltration of mosambi juice. J. Food Eng. 2007, 78, 561-568. [CrossRef]

86. Aghdam, M.A.; Mirsaeedghazi, H.; Aboonajmi, M.; Kianmehr, M.H. Effect of ultrasound on different mechanisms of fouling during membrane clarification of pomegranate juice. Innov. Food Sci. Emerg. Technol. 2015, 30, 127-131. [CrossRef]

87. Koo, C.H.; Mohammad, A.W.; Talib, M.Z.M. Review of the effect of selected physicochemical factors on membrane fouling propensity based on fouling indices. Desalination 2012, 287, 167-177. [CrossRef]

88. Reis, R.; Dumée, L.F.; Tardy, B.L.; Dagastine, R.; Orbell, J.D.; Schutz, J.A.; Duke, M.C. Towards enhanced performance thin-film composite membranes via surface plasma modification. Sci. Rep. 2016, 6, 29206. [CrossRef] [PubMed]

89. Rouquié, C.; Dahdouh, L.; Ricci, J.; Wisniewski, C.; Delalonde, M. Immersed membranes configuration for the microfiltration of fruit-based suspensions. Sep. Purif. Technol. 2019, 216, 25-33. [CrossRef]

90. Varming, C.; Andersen, M.L.; Poll, M. Influence of thermal treatment on black currant (Ribes nigrum L.) juice aroma. J. Agric. Food Chem. 2004, 52, 7628-7636. [CrossRef] [PubMed]

91. Alves, V.D.; Coelhoso, I.M. Orange juice concentration by osmotic evaporation and membrane distillation: A comparative study. J. Food Eng. 2006, 74, 125-133. [CrossRef]

92. Stankiewicz, A.I.; Moulijn, A.J. Process intensification: Transforming chemical engineering. Chem. Eng. Prog. 2000, 96, 22-33.

93. Warczok, J.; Ferrando, M.; Lopez, F.; Guell, C. Concentration of apple and pear juices by nanofiltration at low pressure. J. Food Eng. 2004, 63, 63-70. [CrossRef]

94. Bánvölgyi, S.; Horváth, S.; Békássy-Molnár, E.; Vatai, G. Concentration of blackcurrant (Ribes nigrum L.) juice with nanofiltration. Desalination 2006, 200, 535-536. [CrossRef]

95. Arend, G.D.; Adorno, W.T.; Rezzadori, K.; Di Luccio, M.; Chaves, V.C.; Reginatto, F.H.; Petrus, J.C.C. Concentration of phenolic compounds from strawberry (Fragaria X ananassa Duch) juice by nanofiltration membrane. J. Food Eng. 2017, 201, 36-41. [CrossRef]

96. Santos, F.R.; Catarino, I.; Geraldes, V.; De Pinho, M.N. Concentration and rectification of grape must by nanofiltration. Am. J. Enol. Vitic. 2008, 59, 446-450.

97. Versari, A.; Ferrarini, R.; Parpinello, G.P.; Galassi, S. Concentration of grape must by nanofiltration membranes. Food Bioprod. Process. 2003, 81, 275-278. [CrossRef]

98. Pati, S.; La Notte, D.; Clodoveo, M.L.; Cicco, G.; Esti, M. Reverse osmosis and nanofiltration membranes for the improvement of must quality. Eur. Food Res. Technol. 2014, 239, 595-602. [CrossRef]

99. Medina, B.G.; Garcia, A. Concentration of orange juice by reverse osmosis. J. Food Process Eng. 1988, 10, 217-230. [CrossRef]

100. Álvarez, S.; Riera, F.A.; Álvarez, R.; Coca, J. Permeation of apple aroma compounds in reverse osmosis. Sep. Purif. Technol. 1998, 14, 209-220. [CrossRef]

101. Álvarez, V.; Álvarez, S.; Riera, F.A.; Álvarez, R. Permeate flux prediction in apple juice concentration by reverse osmosis. J. Membr. Sci. 1997, 127, 25-34. [CrossRef]

102. Sheu, M.J.; Wiley, R.C. Preconcentration of apple juice by reverse osmosis. J. Food Sci. 1983, 48, 422-429. [CrossRef]

103. Jesus, D.F.; Leite, M.F.; Silva, L.F.M.; Modesta, R.D.; Matta, V.M.; Cabral, L.M.C. Orange (Citrus sinensis) juice concentration by reverse osmosis. J. Food Eng. 2007, 81, 287-291. [CrossRef]

104. Echavarría, A.P.; Falguera, V.; Torras, C.; Berdún, C.; Pagán, J.; Ibarz, A. Ultrafiltration and reverse osmosis for clarification and concentration of fruit juices at pilot plant scale. LWT Food Sci. Technol. 2012, 46, 189-195. [CrossRef] 
105. Alvarez, S.; Riera, F.A.; Alvarez, R.; Coca, J.; Cuperus, F.P.; Bouwer, S.T.; Boswinkel, C.; van Gemert, R.W.; Veldsink, J.W.; Giorno, L.; et al. A new integrated membrane process for producing clarified apple juice and apple juice aroma concentrate. J. Food Eng. 2000, 46, 109-125. [CrossRef]

106. Calabrò, V.; Jiao, B.; Drioli, E. Theoretical and experimental study on membrane distillation in the concentration of orange juice. Ind. Eng. Chem. Res. 1994, 33, 1803-1808. [CrossRef]

107. Drioli, E.; Jiao, B.; Calabrò, V. The preliminary study on the concentration of orange juice by membrane distillation. In Proceedings of the VII International Citrus Congress, Acireale, Italy, 8-13 March 1992.

108. Kozák, Á.; Békássy Molnár, E.; Vatai, G. Production of black-currant juice concentrate by using membrane distillation. Desalination 2009, 241, 309-314. [CrossRef]

109. Quist-Jensen, C.A.; Macedonio, F.; Conidi, C.; Cassano, A.; Aljlil, S.; Alharbi, O.A.; Drioli, E. Direct contact membrane distillation for the concentration of clarified orange juice. J. Food Eng. 2016, 187, 37-43. [CrossRef]

110. Courel, M.; Dornier, M.; Herry, J.M.; Rios, G.M.; Reynes, M. Effect of operating conditions on water transport during the concentration of sucrose solutions by osmotic distillation. J. Membr. Sci. 2000, 170, 281-289. [CrossRef]

111. Vaillant, F.; Jeanton, E.; Dornier, M.; O’Brien, G.M.; Reynes, M.; Decloux, M. Concentration of passion fruit juice on industrial pilot scale using osmotic evaporation. J. Food Eng. 2001, 47, 195-202. [CrossRef]

112. Gryta, M. Fouling in direct contact membrane distillation process. J. Membr. Sci. 2008, 325, 383-394. [CrossRef]

113. Laganà, F.; Barbieri, G.; Drioli, E. Direct contact membrane distillation: Modelling and concentration experiments. J. Membr. Sci. 2000, 166,1-11. [CrossRef]

114. Sotoft, L.F.; Christensen, K.V.; Andrénsen, R.; Norddahl, B. Full scale plant with membrane based concentration of blackcurrant juice on the basis of laboratory and pilot scale tests. Chem. Eng. Proc. 2012, 54, 12-21. [CrossRef]

115. Cassano, A.; Drioli, E. Concentration of clarified kiwifruit juice by osmotic distillation. J. Food Eng. 2007, 79, 1397-1404. [CrossRef]

116. Cassano, A.; Jiao, B.; Drioli, E. Production of concentrated kiwifruit juice by integrated membrane process. Food Res. Int. 2004, 37, 139-148. [CrossRef]

117. Ravindra Babu, B.; Rastogi, N.K.; Raghavarao, K.S.M.S. Concentration and temperature polarization effects during osmotic membrane distillation. J. Membr. Sci. 2008, 322, 146-153. [CrossRef]

118. Hongvaleerat, C.; Cabral, L.M.C.; Dornier, M.; Reynes, M.; Ningsanond, S. Concentration of pineapple juice by osmotic evaporation. J. Food Eng. 2008, 88, 548-552. [CrossRef]

119. Shaw, P.E.; Lebrun, M.; Ducamp, M.N.; Jordan, M.J.; Goodner, K.L. Pineapple juice concentrated by osmotic evaporation. J. Food Qual. 2002, 25, 39-49. [CrossRef]

120. Versari, A.; Ferrarini, R.; Tornielli, G.B.; Parpinello, G.P.; Gostoli, C.; Celotti, E. Treatment of grape juice by osmotic evaporation. J. Food Sci. 2004, 69, E422-E427. [CrossRef]

121. Cissé, M.; Vaillant, F.; Bouquet, S.; Pallet, D.; Lutin, F.; Reynes, M.; Dorner, M. Athermal concentration by osmotic evaporation of roselle extract, apple and grape juices and impact on quality. Innov. Food Sci. Emerg. Technol. 2011, 12, 352-360. [CrossRef]

122. Valdés, H.; Romero, J.; Saavedra, A.; Plaza, A.; Bubnovich, V. Concentration of noni juice by means of osmotic distillation. J. Membr. Sci. 2009, 330, 205-213. [CrossRef]

123. Cissé, M.; Vaillant, F.; Perez, A.; Dornier, M.; Reynes, M. The quality of orange juice processed by coupling crossflow microfiltration and osmotic evaporation. Int. J. Food Sci. Technol. 2005, 40, 105-116. [CrossRef]

124. Rehman, W.; Zeb, W.; Muhammad, A.; Ali, W.; Younas, M. Osmotic distillation and quality evaluation of sucrose, apple and orange juices in hollow fiber membrane contactor. Chem. Ind. Chem. Eng. Q. 2017, 23, 217-227. [CrossRef]

125. Cassano, A.; Conidi, C.; Drioli, E. A membrane-based process for the valorization of the bergamot juice. Sep. Sci. Technol. 2013, 48, 537-546. [CrossRef]

126. Cassano, A.; Conidi, C.; Drioli, E. Clarification and concentration of pomegranate juice (Punica granatum L.) using membrane processes. J. Food Eng. 2011, 107, 366-373. [CrossRef]

127. Rehman, W.; Muhammad, A.; Khan, Q.A.; Younas, M.; Rezakazemi, M. Pomegranate juice concentration using osmotic distillation with membrane contactor. Sep. Purif. Technol. 2019, 224, 481-489. [CrossRef]

128. Bailey, A.F.G.; Barbe, A.M.; Hogan, P.A.; Johnson, R.A.; Sheng, J. The effect of ultrafiltration on the subsequent concentration of grape juice by osmotic distillation. J. Membr. Sci. 2000, 164, 195-204. [CrossRef]

129. Rehman, W.; Muhammad, A.; Younas, M.; Wu, C.R.; Hu, Y.X.; Li, J.X. Effect of membrane wetting on the performance of PVDF and PTFE membranes in the concentration of pomegranate juice through osmotic distillation. J. Membr. Sci. 2019, 584, 66-78. [CrossRef] 
130. Chanachai, A.; Meksup, K.; Jiraratananon, R. Coating of hydrophobic hollow fiber PVDF membrane with chitosan for protection against wetting and flavor loss in osmotic distillation process. Sep. Purif. Technol. 2010, 72, 217-224. [CrossRef]

131. Rodrigues, R.B.; Menez, H.C.; Cabral, L.M.C.; Dornier, M.; Rios, G.M.; Reynes, M. Evaluation of reverse osmosis and osmotic evaporation to concentrate camu-camu juice (Myciaria dubia). J. Food Eng. 2004, 63, 97-102. [CrossRef]

132. Roozitalab, A.; Raisi, A.; Aroujalian, A. A comparative study on pomegranate juice concentration by osmotic distillation and thermal evaporation processes. Korean J. Chem. Eng. 2019, 36, 1474-1481. [CrossRef]

133. Dincer, C.; Tontul, I.; Topuz, A. A comparative study of black mulberry juice concentrates by thermal evaporation and osmotic distillation as influenced by storage. Innov. Food Sci. Emerg. Technol. 2016, 38, 57-64. [CrossRef]

134. Zambra, C.; Romero, J.; Pino, L.; Saavedra, A.; Sanchez, J. Concentration of cranberry juice by osmotic distillation process. J. Food Eng. 2015, 144, 58-65. [CrossRef]

135. Terki, L.; Kujawski, W.; Kujawa, J.; Kurzawa, M.; Filipiak-Szok, A.; Chrzanowska, E.; Khaled, S.; Madani, K. Implementation of osmotic membrane distillation with various hydrophobic porous membranes for concentration of sugars solutions and preservation of the quality of cactus pear juice. J. Food Eng. 2018, 230, 28-38. [CrossRef]

136. Kujawski, W.; Sobolewska, A.; Jarzynka, K.; Güell, C.; Ferrando, M.; Warczok, J. Application of osmotic membrane distillation process in red grape juice concentration. J. Food Eng. 2013, 116, 801-808. [CrossRef]

137. Souza, A.L.R.; Pagani, M.M.; Dornier, M.; Gomes, F.S.; Tonon, R.V.; Cabral, L.M.C. Concentration of camu-camu juice by the coupling of reverse osmosis and osmotic evaporation processes. J. Food Eng. 2013, 119,7-12. [CrossRef]

138. Cassano, A.; Drioli, E.; Galaverna, G.; Marchelli, R.; Di Silvestro, G.; Cagnasso, P. Clarification and concentration of citrus and carrot juices by integrated membrane processes. J. Food Eng. 2003, 57, 153-163. [CrossRef]

139. Galaverna, G.; Di Silvestro, G.; Cassano, A.; Sforza, S.; Dossena, A.; Drioli, E.; Marchelli, R. A new integrated membrane process for the production of concentrated blood orange juice: Effect on bioactive compounds and antioxidant activity. Food Chem. 2008, 106, 1021-1030. [CrossRef]

140. Aguiar, I.B.; Miranda, N.G.M.; Gomes, F.S.; Santos, M.C.S.; Freitas, D.D.C.; Tonon, R.V.; Cabral, L.M.C. Physicochemical and sensory properties of apple juice concentrated by reverse osmosis and osmotic evaporation. Innov. Food Sci. Emerg. Technol. 2012, 16, 137-142. [CrossRef]

141. Kujawski, W.; Gierszewska-Drużyńska, M.; Warczok, J.; Güell, C. Application of pervaporation and osmotic membrane distillation to the regeneration ofspent solutions from the osmotic food dehydration. Pol. J. Chem. Technol. 2009, 11, 40-44. [CrossRef]

142. Gryta, M. The concentration of spent salt solutions by atmospheric evaporation. Pol. J. Chem. Technol. 2004, 6, 9-12.

143. Ongaratto, R.S.; Lage, P.L.C.; Borges, C.P. Physical properties of potassium pyrophosphate and its use in osmotic evaporation. Chem. Eng. Res. Des. 2015, 104, 497-502. [CrossRef]

144. Ongaratto, R.S.; Menezes, L.; Borges, C.P.; Lage, P.L.C. Osmotic distillation applying potassium pyrophosphate as brine. J. Food Eng. 2018, 228, 69-78. [CrossRef]

145. Vaillant, F.; Cissé, M.; Chaverri, M.; Perez, A.; Dornier, M.; Viquez, F.; Dhuique-Mayer, C. Clarification and concentration of melon juice using membrane processes. Innov. Food Sci. Emerg. Technol. 2005, 6, 213-220. [CrossRef]

146. Cassano, A.; Conidi, C.; Timpone, R.; D'Avella, M.; Drioli, E. A membrane-based process for the clarification and the concentration of the cactus pear juice. J. Food Eng. 2007, 80, 914-921. [CrossRef]

147. Onsekizoglu, P.; Bahceci, K.S.; Acar, M.J. Clarification and the concentration of apple juice using membrane processes: A comparative quality assessment. J. Membr. Sci. 2010, 352, 160-165. [CrossRef]

148. Forero Longas, F.; Velez Pasos, C.A. Optimization of the concentration by osmotic evaporation of passion fruit juice (Passiflora edullis). Dyna Colomb. 2013, 80, 90-98.

149. Forero Longas, F.; Velez Pasos, C.A.; Sandoval, A.P. Ultrafiltration and osmotic evaporation applied to the concentration of cholupa (Passiflora maliformis) juice. Ing. Investig. 2013, 33, 35-40.

150. Onsekizoglu, P. Production of high quality clarified pomegranate juice concentrate by membrane processes. J. Membr. Sci. 2013, 442, 264-271. [CrossRef] 
151. Bagci, P.O.; Akbas, M.; Gulec, H.A.; Bagci, U. Coupling reverse osmosis and osmotic distillation for clarified pomegranate juice concentration: Use of plasma modified reverse osmosis membranes for improved performance. Innov. Food Sci. Emerg. Technol. 2019, 52, 213-220. [CrossRef]

152. Bèlafi-Bakó, K.; Koroknai, B. Enhanced water flux in fruit juice concentration: Coupled operation of osmotic evaporation and membrane distillation. J. Membr. Sci. 2006, 269, 187-193. [CrossRef]

153. Bèlafi-Bakó, K.; Boór, A. Concentration of Cornelian cherry fruit juice by membrane osmotic distillation. Desalin. Water Treat. 2011, 35, 271-274. [CrossRef]

154. Koroknai, B.; Csanádi, Z.; Gubicza, L.; Bèlafi-Bakó, K. Preservation of antioxidant capacity and flux enhancement in concentration of red fruit juices by membrane processes. Desalination 2008, 228, 295-301. [CrossRef]

155. Brazinha, C.; Crespo, J.G. Valorization of food processing streams for obtaining extracts enriched in biologically active compounds. In Integrated Membrane Operations in the Food Production; Cassano, A., Drioli, E., Eds.; Walter De Gruyter: Berlin, Germany, 2014; pp. 295-310.

156. Feron, G.; Bonnarme, P.; Durand, A. Prospects for the microbial production of food flavours. Trends Food Sci. Technol. 1996, 7, 285-293. [CrossRef]

157. Castro-Muñoz, R.; Fíla, V. Membrane-based technologies as an emerging tool for separating high- added-value compounds from natural products. Trends Food Sci. Technol. 2018, 82, 8-20. [CrossRef]

158. Lukin, I.; Merz, J.; Schembecker, G. Techniques for the recovery of volatile aroma compounds from biochemical broth: A review. Flavour Fragr. J. 2018, 33, 203-216. [CrossRef]

159. Cataldo, V.F.; López, J.; Cárcamo, M.; Agosin, E. Chemical vs. biotechnological synthesis of C13-apocarotenoids: Current methods, applications and perspectives. Appl. Microbiol. Biotechnol. 2016, 100, 5703-5718. [CrossRef]

160. Chreptowicz, K.; Wielechowska, M.; Główczyk-Zubek, J.; Rybak, E.; Mierzejewska, J. Production of natural 2-phenylethanol: From biotransformation to purified product. Food Bioprod. Process. 2016, 100, $275-281$. [CrossRef]

161. Saffarionpour, S.; Ottens, M. Recent advances in techniques for flavor recovery in liquid food processing. Food Eng. Rev. 2018, 10, 81-94. [CrossRef]

162. Kimura, K.; Iwata, I.; Nishimura, H. Relationship between acid-catalyzed cyclization of citral and deterioration of lemon flavor. Agric. Biol. Chem. 1982, 46, 1387-1389. [CrossRef]

163. Weerawatanakorn, M.; Wu, J.C.; Pan, M.H.; Ho, C.T. Reactivity and stability of selected flavor compounds. J. Food Drug Anal. 2015, 23, 176-190. [CrossRef]

164. Pereira, C.C.; Ribeiro, C.P.; Nobrega, R.; Borges, C.P. Pervaporative recovery of volatile aroma compounds from fruit juices. J. Membr. Sci. 2006, 274, 1-23. [CrossRef]

165. Bengtsson, E.; Trägårdh, G.; Hallström, B. Recovery and concentration of apple juice aroma compounds by pervaporation. J. Food Eng. 1989, 10, 65-71. [CrossRef]

166. Baudot, A.; Marin, M. Improved recovery of an ester flavor compound by pervaporation coupled with a flash condensation. Ind. Eng. Chem. Res. 1999, 38, 4458-4469. [CrossRef]

167. Cassano, A.; Figoli, A.; Tagarelli, A.; Sindona, G.; Drioli, E. Integrated membrane process for the production of highly nutritional kiwifruit juice. Desalination 2006, 189, 21-30. [CrossRef]

168. Rafia, N.; Aroujalian, A.; Raisi, A. Pervaporative aroma compounds recovery from lemon juice using poly (octyl methyl siloxane) membrane. J. Chem. Technol. Biotechnol. 2011, 86, 534-540. [CrossRef]

169. Raisi, A.; Aroujalian, A. Aroma compound recovery by hydrophobic pervaporation: The effect of membrane thickness and coupling phenomena. Sep. Purif. Technol. 2011,82,53-62. [CrossRef]

170. Toci, A.T.; Boldrin, M.V.Z. Coffee beverages and their aroma compounds. In Handbook of Food Bioengineering Natural and Artificial Flavoring Agents and Food Dyes, 1st ed.; Grumezescu, A.M., Holban, A.M., Eds.; Academic Press: London, UK, 2018; Volume 7, pp. 397-425.

171. Weschenfelder, T.A.; Lantin, P.; Viegas, M.C.; De Castilhos, F.; Scheer, A.D.P. Concentration of aroma compounds from an industrial solution of soluble coffee by pervaporation process. J. Food Eng. 2015, 159, 57-65. [CrossRef]

172. Castro-Muñoz, R.; Buera-Gonzalez, J.; de la Iglesia, O.; Galiano, F.; Fíla, V.; Malankowska, M.; Rubio, C.; Figoli, A.; Tellez, C.; Coronas, J. Towards the dehydration of ethanol using pervaporation cross-linked poly(vinyl alcohol)/graphene oxide membranes. J. Membr. Sci. 2019, 582, 423-434. [CrossRef]

173. Figoli, A.; Tagarelli, A.; Mecchia, A.; Trotta, A.; Cavaliere, B.; Lavecchia, R.; Sindona, G.; Drioli, E. Enzyme-assisted pervaporative recovery of concentrated bergamot peel oils. Desalination 2006, 199, 111-112. [CrossRef] 
174. Figoli, A.; Donato, L.; Carnevale, R.; Tundis, R.; Statti, G.A.; Menichini, F.; Drioli, E. Bergamot essential oil extraction by pervaporation. Desalination 2006, 193, 160-165. [CrossRef]

175. Dawiec-Liśniewska, A.; Szumny, A.; Podstawczyk, D.; Witek-Krowiak, A. Concentration of natural aroma compounds from fruit juice hydrolates by pervaporation in laboratory and semi-technical scale. Part 1 . Base study. Food Chem. 2018, 258, 63-70. [CrossRef] [PubMed]

176. Galiano, F.; Mecchia, A.; Castro-Muñoz, R.; Tagarelli, A.; Lavecchia, R.; Figoli, A. Enzyme-mediated extraction of limonene, linalool and linalyl acetate from bergamot peel oil by pervaporation. J. Membr. Sci. Res. 2019, 5, 187-193.

177. Podstawczyk, D.; Mitkowski, P.T.; Dawiec-Liśniewska, A.; Witek-Krowiak, A. Concentration of natural aroma compounds from fruit juice hydrolates by pervaporation in laboratory and semi-technical scale. Part 2. Economic analysis. J. Clean Prod. 2017, 165, 509-519. [CrossRef]

178. Pereira, C.C.; Rufino, J.R.M.; Habert, A.C.; Nobrega, R.; Cabral, L.M.C.; Borges, C.P. Aroma compounds recovery of tropical fruit juice by pervaporation: Membrane material selection and process evaluation. J. Food Eng. 2005, 66, 77-87. [CrossRef]

179. Isci, A.; Sahin, S.; Sumnu, G. Recovery of strawberry aroma compounds by pervaporation. J. Food Eng. 2006, 75, 36-42. [CrossRef]

180. Figoli, A.; Tagarelli, A.; Cavaliere, B.; Voci, C.; Sindona, G.; Sikdar, S.K.; Drioli, E. Evaluation of pervaporation process of kiwifruit juice by SPME-GC/Ion Trap Mass Spectrometry. Desalination 2010, 250, 1113-1117. [CrossRef]

181. Aroujalian, A.; Raisi, A. Recovery of volatile aroma components from orange juice by pervaporation. J. Membr. Sci. 2007, 303, 154-161. [CrossRef]

182. Raisi, A.; Aroujalian, A.; Kaghazchi, T. Multicomponent pervaporation process for volatile aroma compounds recovery from pomegranate juice. J. Membr. Sci. 2008, 322, 339-348. [CrossRef]

183. Molnár, M.A.; Hornyák, L.; Nagy, R.; Márki, E.; Vatai, G. Enrichment of pineapple aroma compounds from model solutions by sweeping-gas and vacuum-pervaporation. Acta Aliment. 2014, 43, 93-100. [CrossRef]

184. Salgado, C.M.; Fernández-Fernández, E.; Palacio, L.; Carmona, F.J.; Hernández, A.; Prádanos, P. Application of pervaporation and nanofiltration membrane processes for the elaboration of full flavored low alcohol white wines. Food Bioprod. Process. 2017, 101, 11-21. [CrossRef]

(C) 2020 by the authors. Licensee MDPI, Basel, Switzerland. This article is an open access article distributed under the terms and conditions of the Creative Commons Attribution (CC BY) license (http://creativecommons.org/licenses/by/4.0/). 